\title{
Litter type affects the activity of aerobic decomposers in a boreal peatland more than site nutrient and water table regimes
}

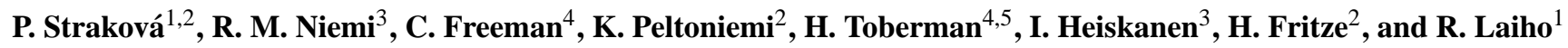 \\ ${ }^{1}$ Peatland Ecology Group, Department of Forest Sciences, Univ. of Helsinki, P.O. Box 27, 00014 Helsinki, Finland \\ ${ }^{2}$ Finnish Forest Research Institute, Vantaa Research Unit, P.O. Box 18, 01301 Vantaa, Finland \\ ${ }^{3}$ Finnish Environment Institute, P.O. Box 140, 00251 Helsinki, Finland \\ ${ }^{4}$ Wolfson Carbon Capture Laboratory, School of Biol. Sciences, University of Wales, Deiniol Road, LL57 2DG Bangor, UK \\ ${ }^{5}$ Environmental Futures Centre, Griffith School of Environment, Griffith University, Nathan, Qld 4111, Australia
}

Received: 6 December 2010 - Published in Biogeosciences Discuss.: 28 February 2011

Revised: 7 September 2011 - Accepted: 11 September 2011 - Published: 27 September 2011

\begin{abstract}
Peatlands are carbon (C) storage ecosystems sustained by a high water table (WT). High WT creates anoxic conditions that suppress the activity of aerobic decomposers and provide conditions for peat accumulation. Peatland function can be dramatically affected by WT drawdown caused by climate and/or land-use change. Aerobic decomposers are directly affected by WT drawdown through environmental factors such as increased oxygenation and nutrient availability. Additionally, they are indirectly affected via changes in plant community composition and litter quality. We studied the relative importance of direct and indirect effects of WT drawdown on aerobic decomposer activity in plant litter at two stages of decomposition (incubated in the field for 1 or 2 years). We did this by profiling 11 extracellular enzymes involved in the mineralization of organic $\mathrm{C}$, nitrogen $(\mathrm{N})$, phosphorus $(\mathrm{P})$ and sulphur. Our study sites represented a three-stage chronosequence from pristine to shortterm (years) and long-term (decades) WT drawdown conditions under two nutrient regimes (bog and fen). The litter types included reflected the prevalent vegetation: Sphagnum mosses, graminoids, shrubs and trees.

Litter type was the main factor shaping microbial activity patterns and explained about $30 \%$ of the variation in enzyme activities and activity allocation. Overall, enzyme activities were higher in vascular plant litters compared to Sphagnum litters, and the allocation of enzyme activities towards $\mathrm{C}$ or nutrient acquisition was related to the initial litter quality
\end{abstract}

(chemical composition). Direct effects of WT regime, site nutrient regime and litter decomposition stage (length of incubation period) summed to only about $40 \%$ of the litter type effect. WT regime alone explained about $5 \%$ of the variation in enzyme activities and activity allocation. Generally, enzyme activity increased following the long-term WT drawdown and the activity allocation turned from $\mathrm{P}$ and $\mathrm{N}$ acquisition towards $\mathrm{C}$ acquisition. This caused an increase in the rate of litter decomposition. The effects of the shortterm WT drawdown were minor compared to those of the long-term WT drawdown: e.g., the increase in the activity of C-acquiring enzymes was up to $120 \%$ (bog) or $320 \%$ (fen) higher after the long-term WT drawdown compared to the short-term WT drawdown. In general, the patterns of microbial activity as well as their responses to WT drawdown depended on peatland type: e.g., the shift in activity allocation to $\mathrm{C}$-acquisition was up to $100 \%$ stronger at the fen compared to the bog.

Our results imply that changes in plant community composition in response to persistent WT drawdown will strongly affect the $\mathrm{C}$ dynamics of peatlands. The predictions of decomposer activity under changing climate and/or land-use thus cannot be based on the direct effects of the changed environment only, but need to consider the indirect effects of environmental changes: the changes in plant community composition, their dependence on peatland type, and their time scale.

\section{Correspondence to: P. Straková}

(petra.strakova@helsinki.fi)

Published by Copernicus Publications on behalf of the European Geosciences Union. 


\section{Introduction}

Peatlands are a significant atmospheric carbon (C) sink due to a long-term imbalance between litter production and decomposition. This imbalance is caused by high water tables (WT) and consequent anoxia that slows down decomposition (e.g., Gorham, 1991; Schulze and Freibauer, 2005). Global climate change is predicted to result in lowered WT in northern peatlands (Gorham, 1991; Roulet et al., 1992; Gitay et al., 2001) via changes in precipitation patterns, and/or increased temperature and evapotranspiration. Another important issue is currently the $\mathrm{C}$ balance of peatlands drained for forestry by ditching, which is the most extensively applied land-use practise on peatlands of Nordic countries and Russia (Minkkinen et al., 2008). Because peatlands represent a large portion of the terrestrial $\mathrm{C}$ pool, it is important to understand their role in the global $\mathrm{C}$ cycle and predict their response to climate and/or land-use change (Limpens et al., 2008).

Persistent lowering of the WT promotes several changes in peatland environmental conditions (Laiho, 2006) that may have direct effects on decomposition. Decreased water content in the surface peat and increased soil aeration may stimulate the activity of aerobic decomposers. Increased peat compaction may, in turn, slow down their activity. Direct effects of WT drawdown on the current vegetation cover include changes in nutrient concentrations because of changes in nutrient availability or root functioning. However, any direct effects may be overruled by the indirect effects through changes in plant community structure (Dorrepaal et al., 2005). These effects have not yet been thoroughly evaluated.

A persistent change in the WT affects plant community structure (Weltzin et al., 2000, 2003; Robroek et al., 2007; Breeuwer et al., 2009), and eventually can lead to a complete turnover of species adapted to the new conditions (Laine et al., 1995a). Such changes tend to be more pronounced in nutrient-rich sites and intensify over time (Laine et al., 1995a). In consequence, the quantity and quality of plant litter produced after the long-term WT drawdown greatly differ from that produced under pristine conditions (Laiho et al., 2003; Straková et al., 2010). Such changes may have important consequences for soil C dynamics (e.g., Hobbie, 1996; Dorrepaal et al., 2005; Cornelissen et al., 2007; Suding et al., 2008).

The structure of the peatland microbial community varies with the plant community (Borgå et al., 1994; Fisk et al., 2003; Thormann et al., 2004; Jaatinen et al., 2007, 2008), and it has been shown that changes in peatland hydrology affect both (Jaatinen et al., 2007; Peltoniemi et al., 2009). Microbial responses in the form of enzyme activities have been detected (Fenner et al., 2005a; Toberman et al., 2010) and may be directly induced by the increased availability of oxygen and/or changes in $\mathrm{pH}$. The presence of bimolecular oxygen activates phenol oxidase enzymes that degrade highly recalcitrant polyphenolic compounds. Phenol oxidase may also activate extracellular hydrolase enzymes by their release from phenolic inhibition; the "enzymic latch theory" (Freeman et al., 2001, 2004). Decomposition is a summative effect of several enzymes produced by the microbial community, and changes in the quality and quantity of litter inputs may affect the activity of each enzyme in a unique manner (Hernández and Hobbie, 2010).

Indirect effects of WT drawdown on the composition and activity of aerobic microbial decomposers in peatlands via changes in plant community structure are, in spite of their significance, still poorly understood (Laiho, 2006; Thormann, 2006). Furthermore, soil nutrient availability may influence community-level decomposition processes (Hobbie and Gough, 2004). Plant communities and, consequently, litter qualities vary along with environmental factors such as $\mathrm{WT}$, soil $\mathrm{pH}$ and nutrient availability that can affect different species in different ways (Hobbie and Gough, 2004). Consequently, it is difficult to predict changes in decomposition rates in situations where the plant community and/or soil factors are changing. As a first step, we focus on the relative importance of substrate quality, soil conditions, and microbial community composition on microbial activity.

The aim of our study was thus to disentangle (1) direct and (2) indirect effects of WT drawdown on the activity of aerobic microbial decomposers in boreal peatland ecosystems, and to link the activity to microbial community composition, litter quality and litter decomposition rates. We characterized microbial activity by quantifying 11 extracellular enzymes involved in mineralization of organic $\mathrm{C}$, nitrogen $(\mathrm{N})$, phosphorus $(\mathrm{P})$ and sulphur $(\mathrm{S})$ in selected litter types, typical of our sites, at two stages of decomposition. By this we aimed to capture both spatial (litter type) and temporal (decomposition stage) variation in microbial activity. The selection of $\mathrm{C}$-, $\mathrm{N}$ - and $\mathrm{P}$-acquiring enzymes was based on previous studies, aiming to include enzymes that play principal roles in the process of organic matter decomposition (e.g., Sinsabaugh, 1994; Allison and Vitousek, 2004; Vepsäläinen et al., 2004; Fenner et al., 2005b; Rejmánková and Sirová, 2007). Additionally, we included the S-acquiring enzyme arylsulphatase, an important enzyme of wetland soils (Kang and Freeman, 1999; Rejmánková and Sirová, 2007).

We hypothesized that WT drawdown has (1) direct positive effects on microbial enzyme activities, caused by improved environmental conditions for aerobic decomposers, and (2) indirect effects, via changes in plant community structure and thus litter quality as the substrate for decomposers. Following WT drawdown, direct effects will be observed as an increase in microbial enzyme activity in litter types common to all WT regimes. Indirect effects will be observed as variation in enzyme activity allocation (standardized activities of each enzyme within a sample) between the different litter types reflecting the changes in the plant communities. Furthermore, we hypothesized that (3) the relatively nutrient-rich fen will have a higher production of 
C-acquiring enzymes and consequently a faster decomposition rate compared to the nutrient-poor bog.

WT in a peatland usually fluctuates within a certain range, depending on season and weather conditions. Such fluctuations have their specific effects on biogeochemical processes (Corstanje and Reddy, 2004), and these may differ from those of a persistent change (Hughes et al., 1999). In this study we focus on a persistent change in average WT. Our results may thus not be applied on temporal WT fluctuations or short-term droughts.

\section{Material and methods}

\subsection{Study sites}

The research was carried out at Lakkasuo, a raised bog complex in Central Finland ( $61^{\circ} 48^{\prime} \mathrm{N}, 24^{\circ} 19^{\prime}$ E, ca. $150 \mathrm{~m}$ a.s.l.). Annual rainfall in this area is $710 \mathrm{~mm}$, of which about onethird falls as snow. The average annual temperature sum (threshold value $5^{\circ} \mathrm{C}$ ) is 1160 degree days and average temperatures for January and July are -8.9 and $15.3^{\circ} \mathrm{C}$, respectively (Finnish Meteorological Institute, Juupajoki weather station 1961-1990).

We had two study sites with differing nutrient regimes: ombrotrophic bog (precipitation-fed, nutrient-poor) and mesotrophic fen (additionally groundwater-fed, more nutrient-rich). Both sites included a pristine control plot, a plot with short-term (ca. 4 years), and a plot with long-term (ca. 40 years) WT drawdown (Laine et al., 2004). Together, these plots formed a gradient from a wet pristine peatland through a drying environment and finally towards a peatland forest ecosystem (Laiho et al., 2003). Within each site, all plots supported the same plant community and had similar soil composition and structure before the WT drawdown. The pristine and long-term drained plots were about $900 \mathrm{~m}^{2}$ and the short-term drained plots about $500 \mathrm{~m}^{2}$.

Water tables in the experimental plots were manipulated by ditching. The long-term WT drawdown had been achieved with practical-scale drainage for forestry in 1961, and the short-term WT drawdown with new ditches for our experimental purposes in 2001. The short-term WT drawdown had led to the average WT being 10 (bog) to 20 (fen) $\mathrm{cm}$ deeper than in the corresponding pristine plots, which is close to the estimate given by Roulet et al. (1992) for the short-term impact of climate change on WT in northern peatlands. In the long-term drained plots, the average WT was 15 (bog) to 40 (fen) $\mathrm{cm}$ deeper than in the pristine plots. We assumed that the initial post-drainage drop in WT was close to that observed in our short-term drained plots, and that further lowering was due to increased evapotranspiration caused by local tree stands (Sarkkola et al., 2010). The difference between fen and bog also largely derives from the higher tree stand evapotranspiration in fens where the tree stands develop faster (Minkkinen et al., 2001). As the WT
Table 1. Experimental layout: litter types included in this study, and the number of replicate litterbags per litter type, plot (water table regime) and site (nutrient regime: fen and bog) prepared for annual recovery. Litter of Betula nana and Pinus sylvestris was present at all sites and plots (common litter) while the other litter types were typical of certain sites or plots (specific litter). The samples represent a subset of an ongoing long-term decomposition study.

\begin{tabular}{l|ccc|ccc}
\hline & \multicolumn{3}{|c|}{ Fen } & \multicolumn{3}{c}{ Bog } \\
Litter type & pristine & STD & LTD & pristine & STD & LTD \\
\hline Carex lasiocarpa leaves & 2 & 2 & & & & \\
Betula nana leaves & 3 & 3 & 3 & 3 & 3 & 3 \\
Pinus sylvestris needles & 2 & 2 & 2 & 2 & 2 & 2 \\
Sphagnum fallax & 3 & 3 & & & & \\
Sphagnum angustifolium & & & 3 & & & 3 \\
Sphagnum balticum & & & & 3 & 3 & \\
Sphagnum fuscum & & & & 2 & 2 & 2 \\
\hline
\end{tabular}

Plots: pristine, undrained; STD, short-term water table drawdown; LTD, long-term water table drawdown.

depth is clearly different (usually lower) next to a drainage ditch than is the average of the drained area (Grieve et al., 1995; Schlotzhauer and Price 1999), no measurements were made next to the ditches (minimum distance $>1 \mathrm{~m}$ for the short-term WT drawdown and $10 \mathrm{~m}$ for the long-term WT drawdown).

The short-term, four-year, WT drawdown had a minor effect on plant community composition. In the long-term, 40 years, the changes in plant community composition were dramatic: WT drawdown transformed an open peatland dominated by Sphagnum and graminoids into a forest ecosystem dominated by pine and birch (Straková et al., 2010). In addition to a lower WT, the change in flora was associated with a drop in $\mathrm{pH}$ and increase in nutrient $(\mathrm{N}$ and $\mathrm{P})$ concentrations of surface peat (Straková et al., 2010).

\subsection{The litter material}

We collected 7 litter types that reflected the dominant species growing under the different nutrient and WT regimes (sites and plots), and were of different plant groups with distinctive chemical composition (Straková et al., 2010). Namely, Carex lasiocarpa leaf litter, Betula nana leaf litter, Pinus sylvestris needle litter and moss litter of Sphagnum angustifolium, Sphagnum balticum, Sphagnum fallax and Sphagnum fuscum. Litter of $B$. nana and P. sylvestris was present in all nutrient and WT regimes ("common litter") and could be used to evaluate the direct effect of WT drawdown on microbial activity. Other litter types in our study were typical of certain nutrient and WT regimes ("specific litter") (Table 1) and thus reflected indirect effects.

Vascular plant litter was collected by harvesting senescent leaves and needles from living plants, moss litter by cutting a $3-5 \mathrm{~cm}$ thick layer below the living moss with scissors (thus, excluding both the upper green and the lower, already 
decomposing, layers). Litter samples were examined and any green or clearly decomposing material was removed. Harvesting took place in September and October 2004 during periods of highest natural litter fall at our sites (Anttila, 2008). Each litter type was air-dried at room temperature $\left(20^{\circ} \mathrm{C}\right)$ to constant mass (about $92-94 \%$ dry mass) and gently mixed. Two sub-samples per litter type and plot were withdrawn to determine initial litter quality (Straková et al., 2010). Dry mass content was determined by drying two sub-samples at $105^{\circ} \mathrm{C}$ overnight.

Of the litter types tested, B. nana leaf litter generally had the highest concentration of nutrients, extractives (substances extractable by hot water) and Klason lignin, and the lowest concentration of holocellulose. The opposite pattern was found for Sphagnum moss litter, except for the concentration of P that was also high in Sphagnum. Detailed chemical characterization of the different litter types was presented by Straková et al. (2010).

\subsection{Decomposition measurements}

Litter decomposition was studied using the litterbag method, which, in spite of some known sources of inaccuracy (Taylor, 1998; Domisch et al., 2000; Kurz-Besson et al., 2005), is the most practical and widely used method for determining mass loss rates of different materials in situ. To minimize the negative effect of air-drying on litter decomposition (Taylor, 1998), litterbags were remoistened with surface water from the test plot before installation. We assumed that this helped the microbial communities typical of the plots to re-colonize the litter. Nylon bags had a mesh size of $1 \times 1 \mathrm{~mm}$ and contained on average $5 \mathrm{~g}$ and $4 \mathrm{~g}$ of air-dried litter for vascular plants and moss, respectively. For each plot (nutrient and WT regime), 2-3 replicates per litter type were prepared for annual recovery (Table 1 ).

Litterbags with vascular plant litter were placed horizontally on the surface where litters naturally fall, always in contact with fallen litter of the same type. Litterbags containing moss litter were installed under the living parts of moss shoots of the given species, where moss litter is naturally formed and begins to decompose. Installation took place in October-November 2004. Incubation periods presented here are years 1 and 2 and represent a subset of an ongoing longterm study.

After each recovery, litterbags were transported to the laboratory where their contents were cleaned by removing all additional (ingrowth) materials, weighed to determine the remaining "fresh" mass and gently homogenized before subsampling. Two sub-samples were taken from each litterbag for the enzyme assays, one for the microbial community composition analysis, and two for dry mass content determination. Dry mass content of the "fresh" samples was determined by drying two sub-samples at $105^{\circ} \mathrm{C}$ overnight. Decomposition rates were expressed as dry mass loss after each incubation period (Appendix A).

\subsection{Enzyme assays}

Measurements of extracellular enzyme activities in soil are very sensitive to sample handling and storage. Further, they are strongly affected by the $\mathrm{pH}$ of the reaction mixture and the incubation temperature. In earlier studies, both "laboratory" ( $\mathrm{pH}$-buffered reaction mixture, incubation temperature higher than in the field) and "natural" conditions have been applied (e.g., Kang and Freeman, 1999; Vepsäläinen et al., 2001; Sinsabaugh et al., 2002; Fenner et al., 2005b; Niemi and Vepsäläinen, 2005; Romaní et al., 2006). The first approach gives information about the potential enzyme activities and especially the quantity of active enzymes (Kang and Freeman, 1999). The second approach more closely reflects the actual natural processes, including the influence of possible litter type or environmentally-related differences in $\mathrm{pH}$, as well as the influence of site temperature that might be rather low in some environments. Outcomes may vary between the two approaches (Freeman et al., 1995).

We measured enzyme activities using both approaches. Henceforth, we refer to the outcomes potential activities (PA) and actual activities (AA) for those assayed in buffered conditions with incubation temperature $20^{\circ} \mathrm{C}$ and non-buffered conditions with incubation temperature $5^{\circ} \mathrm{C}$, respectively. Assays were performed in separate laboratories both having extensive experience with the given approach (e.g., Freeman et al., 2001; Vepsäläinen et al., 2001).

\subsubsection{Potential activities (PA)}

PA were assayed according to Vepsäläinen et al. (2004), using the ZymProfiler® test kit. Substrates used for the assays are listed in Table 2. The substrate and standard solutions were freeze-dried on multiwell plates and stored at $-20^{\circ} \mathrm{C}$ until assayed. Prior to the measurements, $20 \mu \mathrm{l}$ of dimethyl sulfoxide was added to the wells used for chitinase and phosphomonoesterase activity measurements to improve substrate dissolution.

Based on the $\mathrm{pH}$ values of the litters (Appendix A) and peat soil (Table 1 in Straková et al., 2010) at our sites, we used site-specific buffer to control $\mathrm{pH}$ : $0.5 \mathrm{M}$ sodium acetate buffer at $\mathrm{pH} 5.5$ for samples from the fen pristine and shortterm drained plot, and Modified Universal Buffer (MUB) (Tabatabai, 1994) at $\mathrm{pH} 4$ for samples from the fen long-term drained plot and all three bog plots. To examine the effect of the buffer $\mathrm{pH}$ on enzyme activities, samples from the fen long-term drained plot were assayed using both buffers.

Litter samples were stored at $-20^{\circ} \mathrm{C}$ and assayed 6 months after the litterbag recovery. An aliquot of $1.0 \mathrm{~g}$ or $5.0 \mathrm{~g}$ of the frozen foliar or moss litter, respectively, was homogenised in $35 \mathrm{ml}$ of buffer using an OmniMixer (Omni International, USA) for $3 \mathrm{~min}$ at $9600 \mathrm{rev} \mathrm{min}^{-1}$ in an ice bath. The homogenates were further diluted by the buffer to a final dilution of 1:100 and 5:100 for the foliar and moss litter, respectively, and $200 \mu \mathrm{l}$ aliquots of the homogenates were added 
Table 2. Fluorogenic substrates used for the enzyme activity measurements.

\begin{tabular}{|c|c|c|c|c|}
\hline Enzyme & Assay & Substrate & Element & Macromolecule degraded \\
\hline Arylsulphatase & PA & MUF-sulphate & $S$ & Organic sulphur \\
\hline$\alpha$-Glucosidase & PA & MUF- $\alpha$-D-glucopyranoside & $\mathrm{C}$ & Starch and glycogen \\
\hline$\beta$-Glucosidase & AA & $\begin{array}{l}\text { MUF- } \beta \text {-D-glucoside } \\
\text { MUF- } \beta \text {-D-gluconvranoside }\end{array}$ & $\mathrm{C}$ & Cellulose \\
\hline$\beta$-Xylosidase & PA & MUF- $\beta$-D-xylopyranoside & $\mathrm{C}$ & Xylane, xylobiose \\
\hline Cellobiosidase & PA & MUF- $\beta$-cellobiopyranoside & $\mathrm{C}$ & Cellulose \\
\hline Chitinase & $\mathrm{AA}, \mathrm{PA}$ & MUF-N-acetyl- $\beta$-D-glucosaminide & $\mathrm{C}, \mathrm{N}$ & Chitin, chitobiose \\
\hline Phenol oxidase & AA & L-DOPA & $\mathrm{C}$ & Phenolic compounds \\
\hline Phosphomonoesterase & $\mathrm{AA}, \mathrm{PA}$ & MUF-phosphate & $\mathrm{P}$ & Hydrolysis of phosphate esters \\
\hline Phosphodiesterase & PA & bis-MUF-phosphate & $\mathrm{P}$ & Hydrolysis of phosphate diesters \\
\hline Alanine-aminopeptidase & PA & L-alanine-AMC & $\mathrm{N}$ & Oligopeptides $\rightarrow$ amino acids \\
\hline Leucine-aminopeptidase & PA & L-leucine-AMC & $\mathrm{N}$ & Oligopeptides $\rightarrow$ amino acids \\
\hline
\end{tabular}

Assays: AA, actual activities; PA, potential activities (see text for details). Substrates: AMC, 7-amido-4-methylcoumarin; DOPA, dihydroxyphenylalanine; MUF, 4methylumbelliferone.

directly to the freeze-dried substrates to yield substrate concentrations of $500 \mu \mathrm{M}$. Similarly, $200 \mu \mathrm{l}$ aliquots of the homogenate were used in the standard measurements to yield concentrations ranging from 0.5 to $100 \mu \mathrm{M}$ for MUF (4methylumbelliferone) substrates and from 0.1 to $50 \mu \mathrm{M}$ for AMC (7-amido-4-methylcoumarin) substrates.

The reference blank fluorescence of the samples was measured immediately after adding the sample homogenate. Fluorescence values of the end products were obtained from the measurements after $1.5 \mathrm{~h}$ (MUF substrates) or $3 \mathrm{~h}$ (AMC substrates) incubation on a multiwell shaker at $20^{\circ} \mathrm{C}$ in the dark. Fluorescence was measured with a Wallac Victor ${ }^{2 \mathrm{TM}}$ multilabel counter (EG\&G Wallac, Finland) using an excitation filter of $355 \mathrm{~nm}$ and an emission filter of $460 \mathrm{~nm}$.

A mean based on four replicate blanks was subtracted from corresponding enzyme activity measurements, and the MUF and the AMC concentrations were calculated using standard curves. Results from three replicate reaction wells were averaged for each enzyme and litterbag and the enzyme activity was expressed as $\mu \mathrm{mol}$ of substrate converted per minute and per $\mathrm{g}$ of litter dry mass.

\subsubsection{Actual activities (AA)}

AA of $\beta$-glucosidase, chitinase and phosphomonoesterase were assayed according to Güsewell and Freeman (2005) using MUF substrates (Table 2). Litter samples were stored at $4^{\circ} \mathrm{C}$ and assayed within 2 weeks of litterbag recovery. Litter was coarsely chopped with scissors and $1 \mathrm{~cm}^{3}$ of foliar or $2 \mathrm{~cm}^{3}$ of moss litter was mixed with 6 or $7 \mathrm{ml}$ ultra-pure water, respectively, using a Stomacher machine (Seward Colworth model 400, London, UK) to minimize cell disruption. For each of the hydrolases assayed, a $0.5 \mathrm{ml}$ aliquot of the extract (without large litter pieces) was transferred to an Eppendorf reaction vial and $0.25 \mathrm{ml}$ of the appropriate substrate solution (Table 2) was added. Substrates were pre-dissolved in cellosolve (2-ethoxyethanol) as they have minimal solubility in pure water. The concentration of the substrate solution was $400 \mu \mathrm{M}$ for the activity of $\beta$-glucosidase and chitinase, and $200 \mu \mathrm{M}$ for the activity of phosphomonoesterase.

Samples were mixed and incubated at field temperature $\left(5^{\circ} \mathrm{C}\right)$ for $45 \mathrm{~min}$ (phosphomonoesterase) or $60 \mathrm{~min}(\beta$ glucosidase and chitinase). Reactions were terminated by centrifugation at $10000 \mathrm{rpm}$ for $5 \mathrm{~min}$ and the fluorescence of the supernatant was measured immediately on a microplate reader (Perkin-Elmer) at $460 \mathrm{~nm}$ emission and $355 \mathrm{~nm}$ excitation wavelength. For each assay, a range of standard concentrations of MUF in cellosolve was made up in litter extract obtained and incubated under identical conditions as those described above, except for the substrates. Thus, calibration curves accounted for possible interactions between MUF and other compounds in the litter extracts. Enzyme activities were expressed as $\mu \mathrm{mol}$ of substrate converted per minute and per $g$ of litter dry mass. Results from two replicate assays were averaged for each litterbag.

Extracellular phenol oxidase activity was determined according to Fenner et al. (2005a) using $10 \mathrm{~mm}$ L-DOPA (dihydroxyphenylalanine) solution as substrate. A suspension of $1 \mathrm{~cm}^{3}$ litter and $9 \mathrm{ml}$ of ultra-pure water was prepared in the same way as for the hydrolases, and $300 \mu$ aliquots of the extract were transferred into two $1.5 \mathrm{ml}$ Eppendorf reaction vials. Extracts were diluted with $450 \mu \mathrm{l}$ of ultra-pure water, and $750 \mu \mathrm{l}$ of either $10 \mathrm{~mm}$ L-DOPA solution or ultra pure water (control) was added to each vial. The samples were mixed and incubated at field temperature $\left(5^{\circ} \mathrm{C}\right)$ for $9 \mathrm{~min}$ (mixed once at $4.5 \mathrm{~min}$ ). The reaction was terminated by centrifugation at $10000 \mathrm{rpm}$ for $5 \mathrm{~min}$. From each reaction vial, $300 \mu \mathrm{l}$ aliquots of the supernatant were immediately pipetted into three wells of a clear microplate and absorbance was measured at $460 \mathrm{~nm}$. Mean absorbance of the three control wells was subtracted from that of the three L-DOPA wells 
and phenol oxidase activity was calculated using the BeerLambert law:

$c=A / \varepsilon l$

where $c=$ concentration of the L-DOPA product (M); $A=$ average absorbance, calculated as described above; $\varepsilon=$ molar absorbency coefficient for the L-DOPA product $\left(3.7 \times 10^{4}\right)$; $l=$ path length $(\mathrm{cm})$.

Phenol oxidase activity was expressed as $\mu$ mol of the L-DOPA product (2,3-dihydroindole-5,6-quinone-2carboxylate; diqc) produced per minute and per $g$ of litter dry mass. Results from three replicate assays were averaged for each litterbag. All solutions required for the assays were maintained at field temperature $\left(5^{\circ} \mathrm{C}\right)$.

\subsection{Microbial community analyses}

In oxic conditions, aerobic bacteria and fungi are the most important and effective decomposers of organic matter in peatlands (Peltoniemi, 2010 and references therein). To profile the active microbial community, analyses were based on ribosomal RNA extracted directly from the litter samples. RNA is more short-lived compared to DNA and is a better index of the microorganisms that were active at the time of sampling. Total RNA was extracted from deep-frozen ($80^{\circ} \mathrm{C}$ ) litters following Korkama-Rajala et al. (2008) with minor modifications. Reverse transcription of rRNA into its complementary DNA (cDNA) was conducted as in Pennanen et al. (2004) with primer FR1 (Vainio and Hantula, 2000) and with universal bacterial primer R1378 (Nübel et al., 1996). PCR from diluted cDNA template was conducted with fungal 18S rRNA primers and with actinobacterial 16S rRNA primers. The amplified cDNA products were analyzed by denaturing gradient gel electrophoresis (DGGE). The DGGE bands were selected for sequencing, excised, reamplified, purified and sequenced. The partial fungal and actinobacterial DGGE-derived sequences were aligned with sequences retrieved from databases of GenBank/EMBL/DDBJ and RDPII release 9.44 (Cole et al., 2005). True chimeric and clearly non-fungal or non-actinobacterial sequences were eliminated from further analyses. Phylogenetic analyses were conducted as in Jaatinen et al. (2008).

We assumed that discrete bands within a profile differentiated by PCR-DGGE represent different taxa from a microbial consortium. In this study, the data recovered were used to indicate the composition of litter-degrading actinobacteria and fungi in relation to enzyme activities. The microbial data are a subset of a more extensive study on the microbial communities in the same sites (Peltoniemi, 2010).

\subsection{Data analyses}

\subsubsection{General patterns}

Ordination methods were applied due to the presence of multiple intercorrelated variables. We chose linear response models (redundancy analysis; RDA, and principal component analysis; PCA) based on the heterogeneity of the response variable data, i.e., the extent of response variable turnover. This was evaluated using detrended correspondence analysis (DCA) (Lepš and Šmilauer, 2003). Standardized values of enzyme activities were used to minimize scale effects. The ordinations were performed using Canoco for Windows version 4.5 (ter Braak and Šmilauer, 2002). Based on preliminary tests, the AA and PA data of $\beta$-glucosidase, chitinase and phosphomonoesterase (the enzymes assayed by both methods) were merged for the final ordinations in order to simplify the main patterns presented in this paper.

To estimate the proportion of total variation in enzyme activities explained by litter type, nutrient regime, WT and litter decomposition stage (length of incubation period), variation was partitioned by RDA. Enzyme activity values were used as response variables and a group of binary variables describing either litter type, nutrient regime (site), WT regime (plot) or decomposition stage (incubation period; year 1 and 2) was used as explanatory variables while the others were used as covariables. To analyse the overall pattern (including the indirect effects via changes in plant community structure, see hypotheses), all litter types (common and specific, see Table 1) were included in the analysis. The significance of the canonical axes was evaluated using a Monte Carlo permutation test with 499 permutations with a reduced model and covariables as blocks for permutations.

Standardized activities of each enzyme within a sample were calculated (henceforth called "enzyme activity allocation") and PCA was used to explore the main gradient in activity allocation. To examine possible correlation between patterns of phenol oxidase and hydrolases, PCA was carried out using the hydrolase activities as response variables. Correlations between the resulting PCA sample scores and the activity of phenol oxidase were then measured.

\subsubsection{Direct effects of site nutrient and WT regime}

The direct effects of WT drawdown (Hypothesis 1), site nutrient regime (Hypothesis 3 ) or incubation period on enzyme activities were analyzed by repeated measures ANOVA on the common litter, followed by Tukey's post-hoc comparison to test significance among the WT regimes or sites at $p \leq 0.05$. Separate analyses were performed for each enzyme.

The effect of buffer $\mathrm{pH}$ on enzyme activities (estimated for samples from the fen long-term drained plot only) was estimated by ANOVA with litter type and $\mathrm{pH}$ as grouping factors. In all cases, ANOVA was performed using Statistica for Windows version 6.1 (StatSoft, 2003).

\subsubsection{Litter type effects}

The effect of litter type on enzyme activity allocation (Hypothesis 2) was estimated based on the variation partitioning 
results obtained by RDA (described under General patterns).

To explore correlations between the main gradients in enzyme activities and litter quality and mass loss, sample scores from the PCA analysis on enzyme activity allocation (described under General patterns) were plotted with different litter quality parameters and mass loss rates.

\subsubsection{Effects of microbial community composition}

To explore the correlation between the patterns of enzyme activities and microbial community composition, PCA was carried out using binary variables describing presence or absence of microbial DGGE bands as response variables. The resulting PCA sample scores were then used as explanatory variables in RDA, where enzyme activities were used as response variables. Sequences showing a significant correlation with enzyme activities were selected by RDA with manual forward selection of explanatory variables. Measured activities of different enzymes were used as response variables and binary variables describing presence or absence of microbial DGGE bands as explanatory variables. The significance of the contribution of each explanatory variable to the final model was evaluated using a Monte Carlo permutation test with 499 permutations with a reduced model at $p \leq 0.05$.

The number of DGGE bands per sample was used as a surrogate for microbial diversity. To estimate the correlation between patterns of enzyme activities and microbial diversity, RDA was carried out using activities of different enzymes as response variables and the number of DGGE bands per sample as the explanatory variable.

\section{Results}

\subsection{General patterns}

Litter type explained the most variation in enzyme activities (Table 3). Effects of site nutrient and WT regime and litter decomposition stage (incubation period) summed to only about $40 \%$ of the litter type effect.

The main gradient $(32 \%)$ in enzyme activity allocation was attributed to the acquisition of $\mathrm{C}$ and $\mathrm{P}$ (negative mutual correlation, not shown). The second main gradient $(21 \%)$ was attributed to the acquisition of $\mathrm{N}$ (not shown).

\subsection{Litter type effects}

The enzyme activities were generally higher in vascular plant litters compared to Sphagnum litters (Appendix A). In $B$. nana leaf litter, enzyme activities were allocated mainly to $\mathrm{C}$ acquisition whereas $\mathrm{P}$ acquisition was the main activity in Sphagnum and C. lasiocarpa litters (Figs. 1 and 2). Sphagnum fallax litter was distinguished from other moss species by allocating enzyme activities into $\mathrm{N}$ and $\mathrm{S}$ acquisition (not shown).
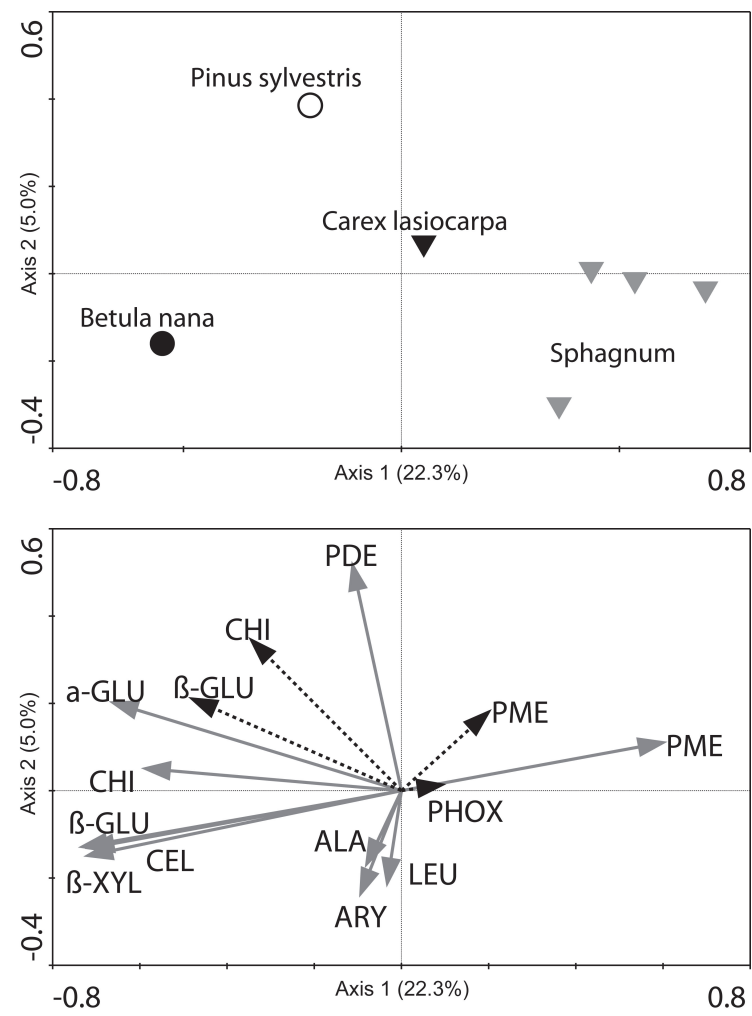

Fig. 1. Differences between litter types based on redundancy analysis (RDA) of the enzyme activity allocation. Dummy variables indicating incubation periods and plots of different nutrient and water table regimes were used as covariables. The first and the second axis account for $22.3 \%$ and $5.0 \%$ of the total variation, respectively. Grey arrows, potential activity; black arrows, actual activity (see Material and Methods). Enzymes: $\alpha$-GLU, $\alpha$ glucosidase; $\beta$-GLU, $\beta$-glucosidase; $\beta$-XYL, $\beta$-xylosidase; ALA, alanine-aminopeptidase; ARY, arylsulphatase; CEL, cellobiosidase; CHI, chitinase; LEU leucine-aminopeptidase; PDE, phosphodiesterase; PHOX phenol oxidase; PME, phosphomonoesterase.

Allocation of enzyme activity towards $\mathrm{C}$ acquisition (increased activity of $\mathrm{C}$ enzymes relative to the activity of $\mathrm{P}$, $\mathrm{N}$ and $\mathrm{S}$ enzymes) was positively correlated with litter mass loss and the initial concentration of extractives (substances extractable by hot water) and Klason lignin (both high in foliar litter and low in Sphagnum), and negatively correlated with the initial concentration of holocellulose (high in Sphagnum and low in foliar litter) (Fig. 2). Allocation of enzyme activity towards $\mathrm{P}$ acquisition (increased activity of $\mathrm{P}$ enzymes relative to the activity of $\mathrm{C}, \mathrm{N}$ and $\mathrm{S}$ enzymes) was positively correlated with $\mathrm{C}: \mathrm{P}$ and $\mathrm{N}: \mathrm{P}$ ratios in vascular plant foliar litter (high in C. lasiocarpa, low in B. nana).

\subsection{Environmental effects}

The long-term WT drawdown had a direct positive effect on the quantitative measures of $\mathrm{C}$-acquiring enzymes while the effect of the short-term WT drawdown was minor. The 
Table 3. Variation partitioning using redundancy analysis (RDA) showing percentage of the total variation in enzyme activities and activity allocation explained by litter type, nutrient and water table regime and litter decomposition stage (incubation period). To analyse the overall pattern rather than the direct effects (see hypotheses), all litter types (common and specific, see Table 1) were included in the analysis. All effects were significant at $p<0.002$.

\begin{tabular}{lcccc}
\hline \multirow{2}{*}{ Main effect } & \multicolumn{2}{c}{$\begin{array}{c}\text { Enzyme activities } \\
\text { Explanatory power (\%) }\end{array}$} & $F$-ratio & Explanatory power (\%) \\
\hline litter type $^{1,2,3}$ & 7.8 & 25.5 & 10.2 & 31.1 \\
water table regime $^{2,3,4}$ & 3.4 & 3.9 & 5.7 & 5.9 \\
site nutrient regime $^{1,3,4}$ & 8.6 & 4.8 & 9.5 & 4.9 \\
incubation period $^{1,2,4}$ & 4.0 & 2.4 & 3.9 & 2.0 \\
\hline
\end{tabular}

Covariables used in the test: ${ }^{1}$ water table regime; ${ }^{2}$ nutrient regime; ${ }^{3}$ incubation period; ${ }^{4}$ litter type.

increase in the activity of $\mathrm{C}$-acquiring enzymes was 10 $120 \%$ (bog) to $110-320 \%$ (fen) higher after the long-term WT drawdown compared to the short-term WT drawdown (Fig. 3). Enzyme activities generally turned from $\mathrm{N}$ and $\mathrm{P}$ acquisition towards $\mathrm{C}$ acquisition following the long-term WT drawdown (Fig. 4). Site nutrient regime had a direct effect on the allocation of enzyme activities. The observed pattern rejected our hypothesis in that enzyme activity actually emphasized $\mathrm{N}$ and $\mathrm{P}$ acquisition at the nutrient-rich fen more than at the nutrient-poor bog (Fig. 4). The shift in allocation of enzyme activities from $\mathrm{N}$ and $\mathrm{P}$ acquisition towards $\mathrm{C}$ acquisition was 10-100\% stronger at the fen compared to the bog (Fig. 4).

\subsection{Effects of microbial community composition}

Microbial community composition explained about $20 \%$ of the total variation in the enzyme activities (not shown). However, no strong patterns emerged and the influence of microbial community on enzyme activity was difficult to interpret. Furthermore, there were no clear changes in enzyme activities between the two stages of litter decomposition, even though the incubation period accounted for some part of the total variation (Table 3 ) and the microbial community composition changed (not shown).

\section{Discussion}

\subsection{Litter type effects overruled the direct effects of WT drawdown}

As hypothesized, litter type was the main factor determining microbial activity in decomposing litter. In reflection of litter quality (Straková et al., 2010), microbial activity of vascular plant litters generally differed from that of mosses, and $C$. lasiocarpa litter was more similar to moss litters than other vascular plant litters. Considering the dramatic changes in environment induced by WT drawdown in our study sites, it is noteworthy that change in litter type (indirect effect of WT
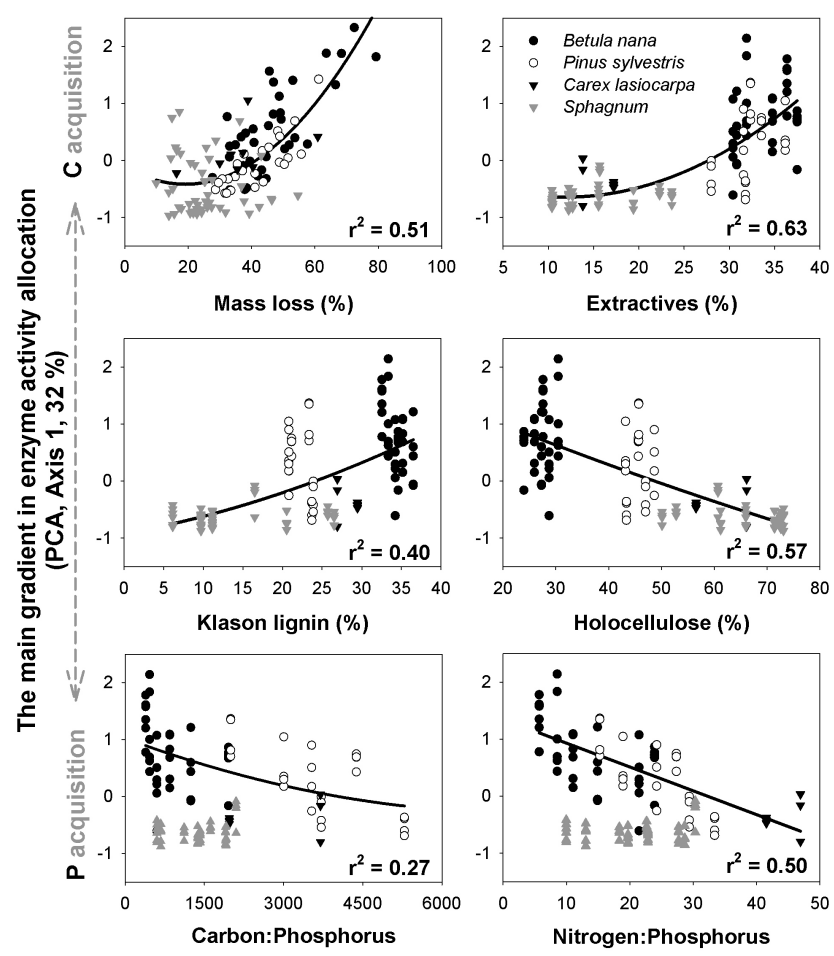

Fig. 2. Correlations between the main gradient in enzyme activity allocation and litter mass loss, initial concentration of extractives (substances easily extractable by hot water), Klason lignin, holocellulose, $\mathrm{C}: \mathrm{P}$ and $\mathrm{N}: \mathrm{P}$ ratio. The main gradient in enzyme activity allocation (vertical axis of the graphs) represents the first axis from principal component analysis (PCA) on standardized activities of each enzyme within a sample. This main gradient accounted for $32 \%$ of the total variation in enzyme activities, and was positively associated with the acquisition of $\mathrm{C}$ (i.e., positively correlated with the standardized activities of C-acquiring enzymes) and negatively associated with the acquisition of $\mathrm{P}$ (i.e., negatively correlated with the standardized activities of P-acquiring enzymes). 


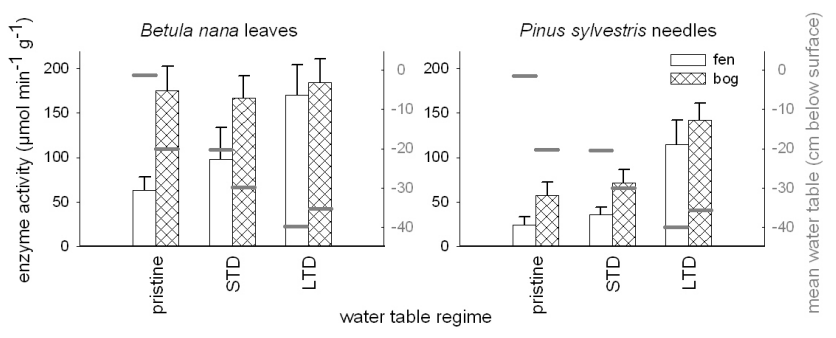

Fig. 3. Direct effects of water table (WT) drawdown and site nutrient regime on activities of $\mathrm{C}$-acquiring enzymes. Enzyme activity data are presented as averages per litter type and plot (nutrient and WT regime), the error bars represent standard error of mean. Site WT regimes: STD, short-term WT drawdown; LTD, long-term WT drawdown.

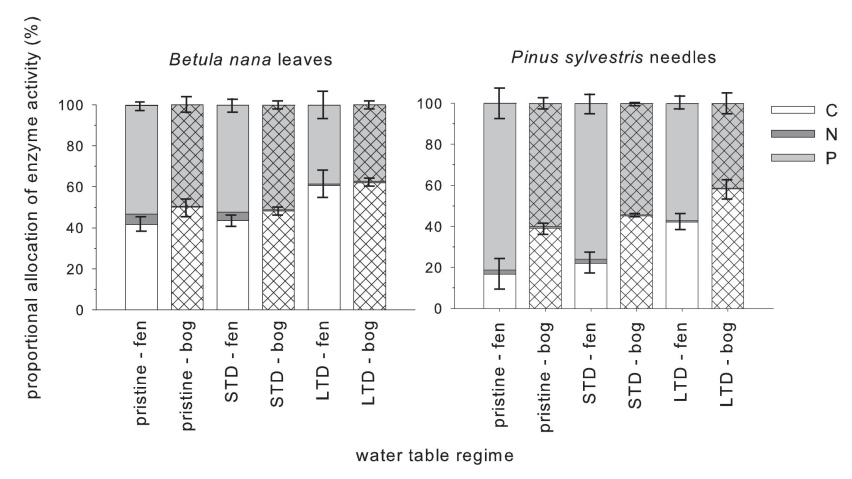

Fig. 4. Direct effects of water table (WT) drawdown and site nutrient regime on enzyme activity allocation. Data are presented as averages per litter type and plot (nutrient and WT regime), the error bars represent standard error of mean (s.e.). For N-acquiring enzymes s.e. was less than 0.5. C, C-acquiring enzymes; N, Nacquiring enzymes; P, P-acquiring enzymes. Site WT regimes: STD, short-term WT drawdown; LTD, long-term WT drawdown. Patterned bar fill marks the bog site.

drawdown) overwhelmed the direct effects of WT drawdown on aerobic microbial activity. Our results are further supported by microbial community composition that revealed similar patterns (Peltoniemi, 2010).

Because litter quality within litter types did not vary much between nutrient and WT regimes (Straková et al., 2010), the detailed characterization of litter quality did not allow us to account for more variation in enzyme activities than the litter type alone. Still, some noteworthy points are revealed when examining the chemical parameters. $\mathrm{P}$ is often the limiting nutrient in boreal peatlands. If P limitation of decomposers is reduced in P-rich litter, decomposers seem to invest into $\mathrm{C}$-acquiring enzymes that produce high litter decomposition rates. This was the case in $B$. nana leaf litter with initially low $\mathrm{C}: \mathrm{P}$ and $\mathrm{N}: \mathrm{P}$ ratio and high concentration of easily assimilable compounds (extractives), but also a high concentration of more recalcitrant compounds captured in the Klason lignin fraction (Fig. 2).
Enzyme activity allocation towards nutrient acquisition is believed to reflect microbial nutrient demand (e.g., Sinsabaugh, 1994; Allison and Vitousek, 2004). Enzyme activity allocation towards P acquisition was detected in Sphagnum moss litters, irrespective of their initial C:P or N:P ratio which varied among species. Unlike other litter types, decomposing Sphagnum litter was heavily colonized by plant roots that had penetrated the litterbags. Some enzymes, particularly phosphatases, may have been produced by roots or associated mycorrhiza (Nannipieri et al., 2002), and thus the activities of P-acquiring enzymes we detected in Sphagnum litter may in part be confounded by these external sources.

We found no clear relationship between the activity of phenol oxidase and the hydrolases in the decomposing litter, unlike in earlier studies where phenol oxidase released extracellular hydrolases from phenolic inhibition in oxic peat soil layers (Freeman et al., 2001, 2004). Our decomposing litters represented rather fresh material compared to peat, and when the litters become more decomposed, i.e., have a higher concentration of recalcitrant compounds, phenol oxidase may play a more important role in regulating decomposition. Phenol oxidase activity tended to be rather high in Sphagnum litter that had high concentrations of hemicellulose and cellulose, but also a relatively high content of p-hydroxy phenols ( $\mathrm{CuO}$ oxidation phenolic products) and other components that were captured in the soluble lignin and Klason lignin fractions (Straková et al., 2010). It seems that in Sphagnum litter, microbes are not able to directly use $\mathrm{C}$ from hemicellulose and cellulose (Hájek et al., 2011) and need to produce phenol oxidase to release $\mathrm{C}$ from the polyphenols and other "lignin-like components". Decomposition of Sphagnum was thus slow compared to other types (Fig. 2), in line with earlier research.

\subsection{Direct environmental effects were significant, but rather small}

\subsubsection{Water table effect}

As hypothesized, WT drawdown had a direct positive effect on microbial activity leading to higher activity of Cacquiring enzymes and faster decomposition rates. In our experiment, litter was generally decomposing in the oxic layer in all WT regimes. Thus, the aerobic decomposer community was not restricted by saturation even in the pristine plots, unlike in peat (Fenner et al., 2005a), and factors other than increased substrate aeration affected microbial activity following WT drawdown. These might include an increase in the aeration and, consequently, nutrient availability of the surface peat, as well as changes in peat and litter $\mathrm{pH}$. 


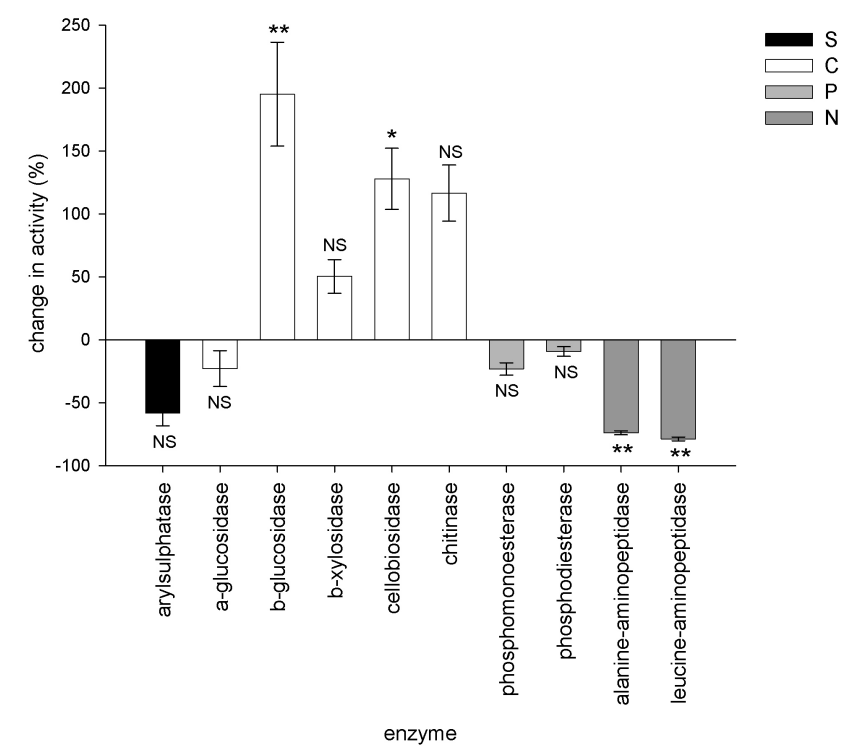

Fig. 5. Effect of $\mathrm{pH}$ on the enzyme activities. Increase (positive values) or decrease (negative values) (\%) of the activity with decreased $\mathrm{pH}$ (activity at $\mathrm{pH} 4$ compared to that at $\mathrm{pH}$ 5.5). Data are presented as averages \pm standard error of mean; $n=16$. ${ }^{* *} p \leq 0.002$; ${ }^{*} p \leq 0.05$; NS nonsignificant. C, C-acquiring enzymes; $\mathrm{N}, \mathrm{N}$ acquiring enzymes; $\mathrm{P}, \mathrm{P}$-acquiring enzymes; $\mathrm{S}$, S-acquiring enzymes.

Peat and litter $\mathrm{pH}$ became more acidic with the long-term WT drawdown at the fen site, probably as a result of isolation from the supply of base-rich groundwater that has a neutralizing effect in pristine fens, enhanced oxidation of organic and inorganic compounds, as well as increased inputs of organic acids and greater uptake of base ions after the establishment of tree cover (Laine et al., 1995b). Lowering of soil $\mathrm{pH}$ following the long-term WT drawdown has been reported previously (Laine et al., 1995a) and affects several processes in peatlands (Laiho, 2006). It is likely that the lowered $\mathrm{pH}$ contributed to the increased activity of $\mathrm{C}$-acquiring enzymes at the fen site following the long-term WT drawdown (Fig. 5; Niemi and Vepsäläinen, 2005) that produced high litter decomposition rates.

Contrary to our findings for decomposing litter, suppression of phenol oxidase (also a C-acquiring enzyme) activity in peat as a result of lowered peat $\mathrm{pH}$ following the long-term WT drawdown was detected at the same sites (Tobermann et al., 2010). For both peat and litter, the same patterns were also observed at the bog although no drop in $\mathrm{pH}$ was detected at this site following the long-term WT drawdown. These observations suggest that there are different factors regulating microbial activity in peat and litter, and these factors may vary between bog and fen sites. Its noteworthy that the effects of WT drawdown on microbial activity were dominant in the long-term when the dramatic changes in vegetation composition (indirect effect of WT drawdown) overruled the direct effects of the changed environment.

\subsubsection{Site effect}

Contrary to our expectations, an increased production of $\mathrm{C}$-acquiring enzymes and faster decomposition rate was observed at the nutrient-poor bog compared to the more nutrient-rich fen site. One possible explanation of this finding is adaptation and specialization of decomposers to plant species characteristic of a given community; a "home field advantage" (Hunt et al., 1988; Gholz et al., 2000; Bragazza et al., 2007; Strickland et al., 2009). Litter types included in common litter represent plant species more typical of bogs, i.e., B. nana and P. sylvestris. This is logical since no typical fen plants can be found in bogs. Such litters may then decompose more slowly in the fen communities that have lower abundance of comparable plant material and associated microbial decomposers, irrespective of a favorable environment. This mechanism may also be involved in the increase of decomposition rates of common litter following WT drawdown as the species are also typical of drained plots (an indirect effect of WT drawdown).

Finally, the site effect we detected might be influenced by peat and litter $\mathrm{pH}$, as discussed above for the WT effect. The activity response to $\mathrm{pH}$ varied among enzymes (Fig. 5) in line with other studies (Niemi and Vepsäläinen, 2005; Kang and Freeman, 1999). Lower $\mathrm{pH}$ resulted in generally higher activities of $\mathrm{C}$-acquiring enzymes in the bog, and $\mathrm{P}-, \mathrm{N}$ - and $\mathrm{S}$-acquiring enzymes in the fen.

\subsection{Vague effects of microbial community composition}

Microbial community composition (presence/absence of a DGGE band) accounted for some part of the total variation in enzyme activities. However, the role of microbial community composition in shaping the patterns of enzyme activities was difficult to interpret. Quantitative data concerning the microbial community would likely be more informative. From the sequences that showed a significant correlation with enzyme activities, fungal sequences were related to various saprotrophic fungi found previously in soil and plant litter. Most of the actinobacterial sequences were related to some unknown clones or isolates coming from various environments, emphasizing the need to examine this microbial group more closely.

Succession of microbial communities as decomposition proceeds and litter quality changes (Kubartová et al., 2007; Peltoniemi, 2010) should be reflected in enzyme activities. However, the effect of decomposition stage (length of incubation period) on enzyme activities in our litters was relatively trivial and of no clear pattern. Stabilisation of enzymes due to the attachment of particles (Gianfreda and Bollag, 1996) could partly explain this absence of variation where one might expect it. Also, litter decomposition in the environment is regulated by substrate availability that cannot be included in laboratory assays. 
Table A1 Enzyme activity ( $\mu$ mol of substrate converted per minute and per g of litter dry weight), mass loss $(\%)$ and $\mathrm{pH}$, mean values per litter type and plot of different nutrient and/or water table regimes with standard error of mean in parenthesis. The standard error indicates variation in enzyme activities and mass loss within a plot.

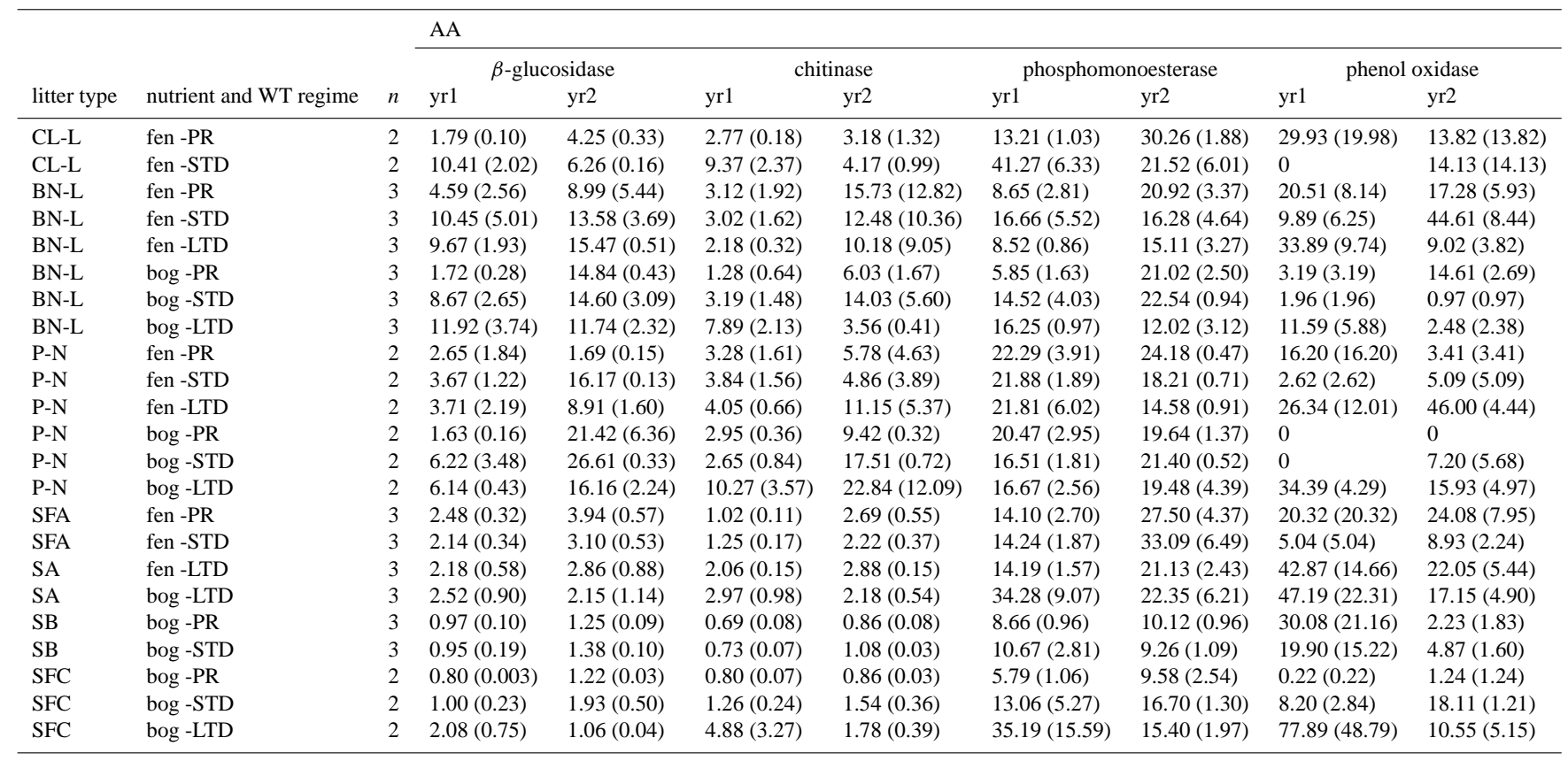

Table A1 Continued.

\begin{tabular}{|c|c|c|c|c|c|c|c|c|c|c|}
\hline \multirow[b]{3}{*}{ litter type } & \multirow[b]{3}{*}{ nutrient and WT regime } & \multirow[b]{3}{*}{$n$} & \multicolumn{8}{|l|}{ PA } \\
\hline & & & \multicolumn{2}{|c|}{$\alpha$-glucosidase } & \multicolumn{2}{|c|}{$\beta$-glucosidase } & \multicolumn{2}{|c|}{ cellobiosidase } & \multicolumn{2}{|c|}{$\beta$-xylosidase } \\
\hline & & & $\mathrm{yr} 1$ & yr2 & yr1 & $\mathrm{yr} 2$ & yr1 & $\mathrm{yr} 2$ & $\mathrm{yr} 1$ & $\mathrm{yr} 2$ \\
\hline CL-L & fen-PR & 2 & $0.59(0.06)$ & $0.61(0.16)$ & $10.83(4.53)$ & $6.50(0.42)$ & $3.60(1.52)$ & $2.54(0.58)$ & $4.54(0.99)$ & $3.45(1.26)$ \\
\hline BN-L & fen -PR & 3 & $0.85(0.13)$ & $1.17(0.07)$ & $10.24(3.80)$ & $5.28(1.58)$ & $2.54(0.74)$ & $1.71(0.12)$ & $3.47(0.44)$ & $2.72(0.37)$ \\
\hline BN-L & fen -STD & 3 & $1.16(0.24)$ & $1.33(0.36)$ & $7.80(2.18)$ & $8.95(1.17)$ & $3.65(1.53)$ & $2.63(0.79)$ & $2.90(0.63)$ & $3.94(0.94)$ \\
\hline BN-L & fen -LTD & 3 & $1.44(0.09)$ & $1.94(0.85)$ & $60.17(18.20)$ & $40.96(3.95)$ & $12.43(1.94)$ & $10.15(2.12)$ & $8.37(0.76)$ & $11.10(2.78)$ \\
\hline BN-L & bog -LTD & 3 & $1.49(0.04)$ & $1.82(0.60)$ & $94.57(4.36)$ & 83.98 (24.54) & $20.29(2.05)$ & $27.14(17.31)$ & $11.70(1.20)$ & $10.28(3.10)$ \\
\hline P-N & fen -PR & 2 & $0.74(0.03)$ & $0.75(0.19)$ & $1.92(0.08)$ & $1.92(0.30)$ & $0.19(0.19)$ & $0.87(0.37)$ & $0.76(0.02)$ & $0.67(0.06)$ \\
\hline P-N & fen -STD & 2 & $0.86(0.13)$ & $1.01(0.08)$ & $5.42(0.21)$ & $9.57(0.28)$ & $1.00(0.06)$ & $2.43(0.12)$ & $1.61(0.13)$ & $2.58(0.13)$ \\
\hline P-N & fen -LTD & 2 & $0.64(0.05)$ & $1.39(0.08)$ & $18.00(0.13)$ & $38.71(22.15)$ & $5.78(1.57)$ & $7.66(1.31)$ & $2.69(0.97)$ & $5.69(0.76)$ \\
\hline P-N & bog -PR & 2 & $0.73(0.15)$ & $1.28(0.43)$ & $15.09(3.21)$ & $26.86(9.08)$ & $2.78(0.96)$ & $5.52(1.81)$ & $2.71(0.38)$ & $3.25(0.85)$ \\
\hline P-N & bog -STD & 2 & $0.72(0.02)$ & $0.74(0.17)$ & 17.35 (2.39) & $24.50(2.15)$ & $3.60(0.36)$ & $5.85(1.87)$ & $2.73(0.13)$ & $3.03(0.79)$ \\
\hline P-N & bog -LTD & 2 & $1.20(0.07)$ & $1.47(0.64)$ & $30.23(8.01)$ & $49.63(13.68)$ & $7.29(0.55)$ & $10.34(2.51)$ & $4.07(0.26)$ & $6.34(2.97)$ \\
\hline SB & bog -PR & 3 & 0 & 0 & $12.51(4.73)$ & $0.24(0.13)$ & 0 & 0 & $2.40(0.95)$ & $0.17(0.08)$ \\
\hline SB & bog -STD & 3 & $0.36(0.29)$ & $0.04(0.02)$ & $8.21(6.48)$ & $1.45(0.16)$ & $1.30(0.94)$ & $0.18(0.04)$ & $2.19(1.58)$ & $0.46(0.01)$ \\
\hline $\mathrm{SFC}$ & bog -PR & 2 & $1.21(0.81)$ & $0.38(0.16)$ & $11.26(8.12)$ & $1.70(0.20)$ & $1.87(0.99)$ & $0.48(0.17)$ & $3.57(2.47)$ & $0.97(0.17)$ \\
\hline SFC & bog -STD & 2 & $1.56(1.15)$ & $0.33(0.09)$ & $8.40(4.32)$ & $5.16(1.54)$ & $1.24(0.60)$ & $0.86(0.23)$ & $2.23(1.34)$ & $1.22(0.16)$ \\
\hline $\mathrm{SFC}$ & bog -LTD & 2 & $1.13(0.09)$ & $0.94(0.24)$ & $11.34(5.91)$ & $6.63(0.71)$ & $2.54(0.07)$ & $1.06(0.31)$ & $3.77(0.46)$ & $2.47(0.32)$ \\
\hline
\end{tabular}


Table A1 Continued.

\begin{tabular}{|c|c|c|c|c|c|c|c|c|c|c|}
\hline \multirow[b]{3}{*}{ litter type } & \multirow[b]{3}{*}{ nutrient and WT regime } & \multirow[b]{3}{*}{$n$} & \multicolumn{8}{|l|}{$\mathrm{PA}$} \\
\hline & & & \multicolumn{2}{|c|}{ chitinase } & \multicolumn{2}{|c|}{ leucine-aminopeptidase } & \multicolumn{2}{|c|}{ alanine-aminopeptidase } & \multicolumn{2}{|c|}{ arylsulphatase } \\
\hline & & & yr1 & $\mathrm{yr} 2$ & $\mathrm{yr} 1$ & yr2 & yr1 & yr2 & $\mathrm{yr} 1$ & $\mathrm{yr} 2$ \\
\hline CL-L & fen -PR & 2 & $10.18(5.01)$ & $5.71(3.11)$ & $4.09(0.69)$ & $6.35(0.79)$ & $3.67(1.52)$ & $5.44(1.88)$ & $0.46(0.34)$ & $0.76(0.67)$ \\
\hline CL-L & fen -STD & 2 & $30.63(12.24)$ & $8.75(0.04)$ & $4.27(1.96)$ & $4.91(1.51)$ & $6.85(4.23)$ & $5.08(2.14)$ & $0.03(0.03)$ & $0.11(0.05)$ \\
\hline BN-L & fen -PR & 3 & $5.44(2.42)$ & $23.10(15.80)$ & $2.85(0.23)$ & $3.59(0.10)$ & $3.11(0.29)$ & $4.33(0.14)$ & $0.28(0.17)$ & $0.59(0.19)$ \\
\hline BN-L & fen -STD & 3 & $15.85(8.59)$ & $54.59(50.33)$ & $2.82(0.02)$ & $6.30(3.34)$ & $5.09(1.69)$ & $4.31(1.54)$ & $0.23(0.05)$ & $0.30(0.14)$ \\
\hline BN-L & fen -LTD & 3 & $48.97(35.58)$ & $64.71(57.89)$ & $0.87(0.16)$ & $0.97(0.31)$ & $1.15(0.14)$ & $1.22(0.30)$ & $0.18(0.09)$ & $0.42(0.33)$ \\
\hline BN-L & bog -PR & 3 & $31.99(12.78)$ & $46.01(26.37)$ & $0.59(0.11)$ & $0.86(0.22)$ & $0.73(0.06)$ & $1.10(0.31)$ & $0.12(0.03)$ & $0.26(0.10)$ \\
\hline BN-L & bog -STD & 3 & $32.50(13.10)$ & $34.70(9.10)$ & $0.62(0.05)$ & $0.77(0.05)$ & $0.64(0.08)$ & $0.89(0.10)$ & $0.18(0.01)$ & $0.33(0.04)$ \\
\hline BN-L & bog -LTD & 3 & $47.74(5.22)$ & $20.04(7.31)$ & $1.02(0.09)$ & $0.98(0.23)$ & $1.05(0.17)$ & $1.19(0.23)$ & $0.24(0.02)$ & $0.20(0.08)$ \\
\hline $\mathrm{P}-\mathrm{N}$ & fen -PR & 2 & $2.99(0.26)$ & $5.04(3.43)$ & $0.75(0.18)$ & $1.81(0.09)$ & $0.96(0.16)$ & $2.06(0.09)$ & $0.06(0.03)$ & $0.07(0.01)$ \\
\hline $\mathrm{P}-\mathrm{N}$ & fen -STD & 2 & $3.82(0.80)$ & $6.75(1.92)$ & $1.24(0.23)$ & $2.33(0.71)$ & $1.43(0.43)$ & $2.06(0.32)$ & $0.05(0.01)$ & $0.18(0.04)$ \\
\hline P-N & fen -LTD & 2 & $19.75(3.47)$ & $28.48(7.62)$ & $0.35(0.05)$ & $1.27(0.27)$ & $0.57(0.02)$ & $1.08(0.07)$ & $0.04(0.02)$ & $0.10(0.001)$ \\
\hline $\mathrm{P}-\mathrm{N}$ & bog -PR & 2 & $9.67(1.20)$ & $11.92(1.85)$ & $0.49(0.21)$ & $0.56(0.16)$ & $0.57(0.23)$ & $0.72(0.18)$ & $0.04(0.04)$ & $0.12(0.05)$ \\
\hline $\mathrm{P}-\mathrm{N}$ & bog -STD & 2 & $11.47(0.72)$ & $12.09(1.29)$ & $0.35(0.02)$ & $0.41(0.03)$ & $0.36(0.01)$ & $0.60(0.18)$ & $0.04(0.01)$ & $0.08(0.02)$ \\
\hline P-N & bog -LTD & 2 & $20.56(0.80)$ & $47.07(16.63)$ & $0.36(0.03)$ & $0.84(0.45)$ & $0.48(0.05)$ & $1.09(0.50)$ & $0.08(0.01)$ & $0.16(0.14)$ \\
\hline SFA & fen -PR & 3 & $5.79(1.64)$ & $0.51(0.08)$ & $1.12(0.22)$ & $2.81(0.44)$ & $1.13(0.16)$ & $2.63(0.51)$ & $7.75(1.44)$ & $0.34(0.20)$ \\
\hline SFA & fen -STD & 3 & $3.25(1.43)$ & $1.28(0.29)$ & $4.40(1.63)$ & $3.77(0.08)$ & $3.32(0.94)$ & $3.09(0.42)$ & $0.26(0.17)$ & $0.04(0.04)$ \\
\hline SA & fen -LTD & 3 & $17.80(10.02)$ & $18.34(5.60)$ & $0.32(0.08)$ & $0.36(0.13)$ & $0.44(0.12)$ & $0.52(0.23)$ & 0 & 0 \\
\hline SA & bog -LTD & 3 & $19.60(3.09)$ & $3.61(1.00)$ & $0.27(0.01)$ & $0.69(0.03)$ & $0.36(0.01)$ & $0.91(0.03)$ & 0 & 0 \\
\hline SB & bog -PR & 3 & $6.59(2.34)$ & $0.64(0.20)$ & $0.25(0.13)$ & $0.46(0.05)$ & $0.31(0.14)$ & $0.54(0.04)$ & 0 & 0 \\
\hline SB & bog -STD & 3 & $8.82(6.26)$ & $1.53(0.35)$ & $0.50(0.16)$ & $0.40(0.02)$ & $0.58(0.16)$ & $0.51(0.04)$ & 0 & 0 \\
\hline $\mathrm{SFC}$ & bog -PR & 2 & $5.92(3.43)$ & $2.71(0.53)$ & $0.30(0.14)$ & $0.44(0.02)$ & $0.34(0.17)$ & $0.56(0.05)$ & 0 & 0 \\
\hline SFC & bog -STD & 2 & $8.19(6.32)$ & $3.10(0.001)$ & $0.31(0.11)$ & $0.37(0.03)$ & $0.34(0.12)$ & $0.46(0.05)$ & 0 & 0 \\
\hline SFC & bog -LTD & 2 & $28.93(9.62)$ & $13.95(0.24)$ & $0.21(0.02)$ & $0.20(0.01)$ & $0.25(0.04)$ & $0.26(0.04)$ & 0 & 0 \\
\hline
\end{tabular}

Table A1 Continued.

\begin{tabular}{|c|c|c|c|c|c|c|c|c|c|c|}
\hline \multirow[b]{3}{*}{ litter type } & \multirow[b]{3}{*}{ nutrient and WT regime } & \multirow[b]{3}{*}{$n$} & \multicolumn{4}{|l|}{$\mathrm{PA}$} & \multicolumn{2}{|l|}{ mass loss } & \multicolumn{2}{|l|}{$\mathrm{pH}$} \\
\hline & & & \multicolumn{2}{|c|}{ phosphomonoesterase } & \multicolumn{2}{|c|}{ phosphodiesterase } & \multirow[b]{2}{*}{ yr1 } & \multirow[b]{2}{*}{$\mathrm{yr} 2$} & \multirow[b]{2}{*}{ yr1 } & \multirow[b]{2}{*}{$\mathrm{yr} 2$} \\
\hline & & & $\mathrm{yr} 1$ & $\mathrm{yr} 2$ & $\mathrm{yr} 1$ & $\mathrm{yr} 2$ & & & & \\
\hline CL-L & fen -PR & 2 & $74.10(26.35)$ & $130.17(63.66)$ & $23.23(0.85)$ & $26.85(2.66)$ & $23.18(6.82)$ & $38.85(1.59)$ & $5.64(0.16)$ & $5.12(0.64)$ \\
\hline CL-L & fen -STD & 2 & $195.39(38.92)$ & $161.58(38.53)$ & $28.08(18.37)$ & $21.61(4.86)$ & $36.20(2.65)$ & $48.24(12.68)$ & $5.31(0.21)$ & $5.27(0.44)$ \\
\hline $\mathrm{BN}-\mathrm{L}$ & fen -PR & 3 & $46.08(4.41)$ & $64.54(17.62)$ & $6.36(0.73)$ & $7.97(0.64)$ & $36.17(1.51)$ & $45.35(2.16)$ & $4.67(0.04)$ & $4.81(0.07)$ \\
\hline $\mathrm{BN}-\mathrm{L}$ & fen -STD & 3 & $109.28(51.71)$ & $105.82(63.31)$ & $8.89(2.46)$ & $9.92(4.89)$ & $35.14(5.01)$ & $53.67(12.91)$ & $5.54(0.18)$ & $5.65(0.22)$ \\
\hline $\mathrm{BN}-\mathrm{L}$ & fen -LTD & 3 & $102.32(15.81)$ & $119.41(84.77)$ & $9.68(2.15)$ & $11.91(7.51)$ & $41.34(3.91)$ & $53.18(7.73)$ & $4.15(0.21)$ & $5.65(0.14)$ \\
\hline $\mathrm{BN}-\mathrm{L}$ & bog -PR & 3 & $104.83(11.91)$ & $169.38(7.33)$ & $9.64(0.71)$ & $17.70(4.26)$ & $40.28(4.00)$ & $50.54(8.37)$ & $4.80(0.53)$ & $4.85(0.18)$ \\
\hline $\mathrm{BN}-\mathrm{L}$ & bog -STD & 3 & $107.47(13.23)$ & $169.76(26.18)$ & $14.76(2.97)$ & $18.40(3.96)$ & $43.86(1.67)$ & $62.29(5.22)$ & $4.47(0.05)$ & $4.79(0.07)$ \\
\hline $\mathrm{BN}-\mathrm{L}$ & bog -LTD & 3 & $88.50(9.11)$ & $88.59(28.13)$ & $9.96(1.38)$ & $6.79(1.75)$ & $42.69(5.21)$ & $60.22(6.47)$ & $4.52(0.06)$ & $4.53(0.19)$ \\
\hline $\mathrm{P}-\mathrm{N}$ & fen -PR & 2 & $66.11(15.57)$ & $82.64(15.60)$ & $12.01(0.82)$ & $15.18(1.52)$ & $32.58(0.93)$ & $42.43(1.32)$ & $4.47(0.12)$ & $4.46(0.21)$ \\
\hline $\mathrm{P}-\mathrm{N}$ & fen -STD & 2 & $88.98(23.81)$ & $87.97(0.84)$ & $17.30(5.45)$ & $17.18(0.49)$ & $32.91(4.24)$ & $50.18(1.34)$ & $4.42(0.06)$ & $4.78(0.01)$ \\
\hline $\mathrm{P}-\mathrm{N}$ & fen -LTD & 2 & $85.00(8.21)$ & $88.01(35.90)$ & $10.83(0.90)$ & $16.25(1.53)$ & $37.98(3.11)$ & $54.72(1.01)$ & $4.15(0.28)$ & $4.03(0.15)$ \\
\hline $\mathrm{P}-\mathrm{N}$ & bog -PR & 2 & $44.18(4.97)$ & $72.53(1.54)$ & $8.01(1.90)$ & $9.13(1.30)$ & $32.43(0.24)$ & $49.34(1.03)$ & $4.65(0.09)$ & $4.28(0.16)$ \\
\hline $\mathrm{P}-\mathrm{N}$ & bog -STD & 2 & $43.00(3.57)$ & $72.94(8.50)$ & $8.84(0.69)$ & $9.48(0.62)$ & $30.21(0.58)$ & $46.21(2.74)$ & $4.39(0.13)$ & $4.29(0.18)$ \\
\hline $\mathrm{P}-\mathrm{N}$ & bog -LTD & 2 & $36.55(1.40)$ & $115.36(40.34)$ & $8.88(0.26)$ & $8.86(3.68)$ & $36.59(1.06)$ & $53.35(7.87)$ & $3.53(0.07)$ & $3.65(0.17)$ \\
\hline SFA & fen -PR & 3 & $416.44(21.73)$ & $57.38(8.93)$ & $26.76(4.02)$ & $4.21(0.77)$ & $16.07(0.68)$ & $25.30(1.55)$ & $3.94(0.02)$ & $3.76(0.16)$ \\
\hline SFA & fen -STD & 3 & $208.00(140.91)$ & $53.20(12.62)$ & $14.09(8.40)$ & $4.09(0.55)$ & $32.90(3.69)$ & $42.32(8.48)$ & $4.97(0.23)$ & $4.18(0.10)$ \\
\hline SA & fen -LTD & 3 & $217.12(77.80)$ & $179.54(62.04)$ & $10.22(4.05)$ & $13.46(4.43)$ & $27.06(1.64)$ & $30.22(10.26)$ & $4.46(0.03)$ & $4.47(0.05)$ \\
\hline SA & bog -LTD & 3 & $287.32(18.72)$ & $52.57(8.88)$ & $14.48(0.96)$ & $3.03(0.26)$ & $26.55(1.11)$ & $42.73(2.06)$ & $4.05(0.03)$ & $4.06(0.05)$ \\
\hline SB & bog -PR & 3 & $97.03(33.06)$ & $28.82(4.30)$ & $12.39(5.01)$ & $4.75(0.31)$ & $14.91(0.51)$ & $19.44(2.77)$ & $4.46(0.50)$ & $3.84(0.13)$ \\
\hline SB & bog -STD & 3 & $95.11(54.26)$ & $51.47(2.07)$ & $7.40(4.16)$ & $5.10(1.41)$ & $21.36(0.42)$ & $26.25(2.83)$ & $4.85(0.05)$ & $4.52(0.13)$ \\
\hline SFC & bog -PR & 2 & $74.92(50.78)$ & $36.83(6.10)$ & $10.02(7.04)$ & $4.27(0.23)$ & $16.21(1.65)$ & $23.60(0.58)$ & $4.50(0.24)$ & $4.57(0.14)$ \\
\hline SFC & bog -STD & 2 & $151.21(103.43)$ & $53.13(1.44)$ & $8.85(6.27)$ & $4.44(0.01)$ & $16.75(0.31)$ & $23.55(3.21)$ & $4.10(0.17)$ & $4.13(0.19)$ \\
\hline SFC & bog -LTD & 2 & $260.31(13.84)$ & $191.28(59.49)$ & $15.08(3.57)$ & $10.76(0.45)$ & $19.18(1.54)$ & $26.51(1.06)$ & $3.97(0.19)$ & $3.85(0.11)$ \\
\hline
\end{tabular}

AA, actual activities; PA, potential activities (see Material and Methods); $n$, number of samples per litter type and nutrient and/or water table (WT) regime; yr1, litter decomposing for one year; yr2, litter decomposing for two years. WT regimes: LTD, long-term WT drawdown; PR, pristine; STD, short-term WT drawdown. Litter types: BN-L, Betula nana leaves; CL-L, Carex lasiocarpa leaves; P-N, Pinus sylvestris needles; SA, Sphagnum angustifolium; SB, S. balticum; SFA, S. fallax; SFC, S. fuscum. 


\section{Conclusions}

We combined analyses of litter quality, litter decomposition rates, microbial community composition, and extracellular enzyme activities to estimate how WT drawdown may affect litter decomposition and element cycling in a range of peatland sites differing in soil nutrient availability. These factors have never before been examined simultaneously.

Litter type was the main factor shaping the patterns of enzyme activities and overruled the direct effects of WT drawdown on aerobic microbial activity. Our results imply that change in the structure of plant communities in response to persistent WT drawdown will strongly affect the C dynamics of peatlands. The dynamics of plant community composition and consequent litterfall need to be considered along with soil factors when estimating the impacts of global climate change on $\mathrm{C}$ cycling in peatlands. The soil factors need to include $\mathrm{pH}$, since that also changes along with persistent WT drawdown.

Enzyme activities generally turned from $\mathrm{N}$ and $\mathrm{P}$ acquisition towards $\mathrm{C}$ acquisition following the long-term WT drawdown, suggesting reduced nutrient limitation of decomposers. Decomposers then seemed to invest into C-acquiring enzymes that produced high litter decomposition rates.

Sphagnum mosses exhibited low enzyme activities and decomposed slowly compared to vascular plants. Yet, we observed abundant fine root growth and an enzyme activity allocation shift towards $\mathrm{P}$ acquisition. This may have been induced by the roots of arboreal plants and suggests that mosses or their degradation products may be used as a substrate by trees and shrubs. Since Sphagnum is generally considered to be a hostile environment, this feature would deserve further study.

Coupled with the findings of earlier research, our observations suggest that different factors regulate microbial activity in peat and in the litter that contributes new $\mathrm{C}$ to this important pool. These factors also vary between bog and fen sites. Thus, $\mathrm{C}$ cycling in litter and in peat should be examined separately in order to improve our understanding of $\mathrm{C}$ dynamics under changing environmental conditions (see also Laiho, 2006). To further complicate reaching clear conclusions about peatland responses to climate change, our results emphasize that bogs and fens may respond in different manners, and that there may be notable spatial variation related to plant community composition.

Our results emphasize the importance of considering the time-scale of the environmental changes. The effects of environmental changes on soil processes are getting dominant in the long-term, following the dramatic changes in vegetation composition (indirect effect of the environmental changes).
Acknowledgements. This study was supported by the Academy of Finland (projects 104425 and 106197), a Royal Society International Collaboration Grant, the European Science Foundation, and the Graduate School of Forest Sciences. We thank Kaisa Heinonen, Nathalie Fenner, Tim Jones, Tim Ellis and Satu Repo for their valuable help with the laboratory work, Juul Limpens and Björn Berg for their thorough and constructive comments on the manuscript, and Michael Hardman for revising the language.

Edited by: D. Zona

\section{References}

Allison, S. D. and Vitousek, P. M.: Extracellular enzyme activities and carbon chemistry as drivers of tropical plant litter decomposition, Biotropica, 36, 285-296, 2004.

Anttila, J.: Lyhyt- ja pitkäaikaisen kuivatuksen aiheuttamat muutokset soiden maanpäällisen karikkeen tuotossa [Effects of shortterm and long-term water-level drawdown on the above-ground litter inputs into peatland ecosystems], M.Sc. thesis, Department of Forest Ecology, University of Helsinki, Finland, 56 pp, 2008.

Borgå, P., Nilsson, M., and Tunlid, A.: Bacterial communities in peat in relation to botanical composition as revealed by phospholipid fatty acid analysis, Soil Biol. Biochem., 26, 841-848, 1994.

Bragazza, L., Siffi, C., Iacumin, P., and Gerdol, R.: Mass loss and nutrient release during litter decay in peatland: The role of microbial adaptability to litter chemistry, Soil Biol. Biochem., 39, 257-267, 2007.

Breeuwer, A. J. G., Robroek, B. J. M., Limpens, J., Heijmans, M. M. P. D., Schouten, M. G. C., and Berendse, F.: Decreased summer water table depth affects peatland vegetation, Basic Appl. Ecol., 10, 330-339, 2009.

Cole, J. R., Chai, B., Farris, R. J., Wang, Q., Kulam, S. A., McGarrell, D. M., Garrity, G. M., and Tiedje, J. M.: The Ribosomal Database Project (RDP-II): sequences and tools for highthroughput rRNA analysis. Nucleic Acids Research 33 (Database Issue), D294-D296, 2005.

Cornelissen, J. H., van Bodegom, P. M., Aerts, R., Callaghan, T. V., van Logtestijn, R. S., Alatalo, J., Chapin, F. S., Gerdol, R., Gudmundsson, J., Gwynn-Jones, D., Hartley, A. E., Hik, D. S., Hofgaard, A., Jónsdóttir, I. S., Karlsson, S., Klein, J. A., Laundre, J., Magnusson, B., Michelsen, A., Molau, U., Onipchenko, V. G., Quested, H. M., Sandvik, S. M., Schmidt, I. K., Shaver, G. R., Solheim, B., Soudzilovskaia, N. A., Stenström, A., Tolvanen, A., Totland, Ø., Wada, N., Welker, and J. M., Zhao.: Global negative vegetation feedback to climate warming responses of leaf litter decomposition rates in cold biomes, Ecol. Lett., 10, 619627, 2007.

Corstanje, R. and Reddy, K. R.: Response of biogeochemical indicators to a drawdown and subsequent reflood, J. Environ. Qual., 33, 2357-2366, 2004.

Domisch, T., Finér, L., Laiho, R., Karsisto, M., and Laine, J.: Decomposition of Scots pine litter and the fate of released carbon in pristine and drained pine mires, Soil Biol. Biochem., 32, 15711580, 2000.

Dorrepaal, E., Cornelissen, J. H. C., Aerts, R., Wallén, B., and van Logtestijn, R. S. P.: Are growth forms consistent predictors of 
leaf litter quality and decomposability across peatlands along a latitudinal gradient?, Jour. Ecol., 93, 817-828, 2005.

Farrish, K. W. and Grigal, D. G.: Decomposition in an ombrotrophic bog and a minerotrophic fen in Minnesota, Soil Sci., 145, 353-358, 1988.

Fenner, N., Freeman, C., and Reynolds, B.: Hydrological effects on the diversity of phenolic degrading bacteria in a peatland: implications for carbon cycling, Soil Biol. Biochem., 37, 1277-1287, 2005a.

Fenner, N., Freeman, C., and Reynolds, B.: Observations of a seasonally shifting thermal optimum in peatland carbon-cycling processes; implications for the global carbon cycle and soil enzyme methodologies, Soil Biol. Biochem., 37, 1814-1821, 2005b.

Fisk, M. C., Ruether, K. F., and Yavitt, J. B.: Microbial activity and functional composition among northern peatland ecosystems, Soil Biol. Biochem., 35, 591-602, 2003.

Freeman, C., Liska, G., Ostle, N. J., Jones, S. E., and Lock, M. A.: The use of fluorogenic substrates for measuring enzyme activity in peatlands, Plant Soil, 175, 147-152, 1995.

Freeman, C., Ostle, N., and Kang, H.: An enzymic 'latch' on a global carbon store, Nature, 409, 149, 2001.

Freeman, C., Ostle, N. J., Fenner, N., and Kang, H.: A regulatory role for phenol oxidase during decomposition in peatlands, Soil Biol. Biochem., 36, 1663-1667, 2004.

Gholz, H. L., Wedin, D. A., Smitherman, S. M., Harmon, M. E., and Parton, W. J.: Long-term dynamics of pine and hardwood litter in contrasting environments: toward a global model of decomposition, Glob. Change Biol., 6, 751-765, 2000.

Gianfreda, L. and Bollag, J. M.: Influence of natural and anthropogenic factors on enzyme activity in soil, in: Soil Biochemistry, edited by: Stotzky, G. and Bollag, J. M., Mercel Dekker, New York, 123-193, 1996.

Gitay, H., Brown, S., Easterling, W., Jallow, B., Antle, J., Apps, M. J., Beamish, R., Chapin, T., Cramer, W., Frangi, J., Laine, J., Erda, L., Magnuson, J., Noble, I., Price, J., Prowse, T., Root, T., Schulze, E., Sirotenko, O., Sohngen, B., and Soussana, J.: Ecosystems and their goods and services, in: Climate Change 2001: Impacts, Adaptation and Vulnerability, edited by: McCarthy, J. J., Canziani, O. F., Leary, N. A., Dokken, D. J., and White, K. S., Cambridge University Press, Cambridge, 235-342, 2001

Gorham, E.: Northern peatlands: role in the carbon cycle and probable responses to climatic warming, Ecol. Appl., 1, 182-195, 1991.

Grieve, I. C., Gilvear, D. G., and Bryant, R. G.: Hydrochemical and water source variations across a floodplain mire, Insh Marshes, Scotland, Hydrol. Process., 9, 99-110, 1995.

Güsewell, S. and Freeman, C.: Phosphorus-limited decomposition of litter from phosphorus-limited plants grown in strong sunlight, Funct. Ecol., 19, 582-593, 2005.

Hájek, T., Ballance, S., Limpens, J., Zijlstra, M., and Verhoeven, J. T. A.: Cell-wall polysaccharides play an important role in decay resistance of Sphagnum and actively depressed decomposition in vitro, Biogeochemistry, 103, 45-57, 2011.

Hernández, D. L. and Hobbie, S. E.: The effects of substrate composition, quantity, and diversity on microbial activity, Plant Soil, 335, 397-397, 2010.

Hobbie, S. E.: Temperature and plant species control over litter decomposition in Alaskan tundra, Ecol. Monogr., 66, 503-522,
1996.

Hobbie, S. E. and Gough, L.: Litter decomposition in moist acidic and non-acidic tundra with different glacial histories, Oecologia, 140, 113-124, 2004.

Hughes, S., Dowrick, D. J., Freeman, C., Hudson, J. A., and Reynolds, B.: Methane emissions from a gully mire in midWales, UK under consecutive summer water table drawdown, Environ. Sci. Technol., 33, 362-365, 1999.

Hunt, H. W., Ingham, E. R., Coleman, D. C., Elliot, E. T., and Reid, C. P. P.: Nitrogen limitation of production and decomposition in prairie, mountain meadow and pine forest, Ecology, 69, 10091016, 1988.

Jaatinen, K., Fritze, H., Laine, J., and Laiho, R.: Effects of shortand long-term water-level drawdown on the populations and activity of aerobic decomposers in a boreal peatland, Glob. Change Biol., 13, 491-510, 2007.

Jaatinen, K., Laiho, R., Vuorenmaa, A., del Castillo, U., Minkkinen, K., Pennanen, T., Penttilä, T., and Fritze, H.: Responses of aerobic microbial communities and soil respiration to a waterlevel drawdown in a northern boreal fen, Environ. Microbiol., 10, 339-353, 2008.

Kang, H. and Freeman, C.: Phosphatase and arylsulphatase activities in wetland soils: annual variation and controlling factors, Soil Biol. Biochem., 31, 449-454, 1999.

Korkama-Rajala, T., Müller, M., and Pennanen, T.: Decomposition and fungi of needle litter from slow- and fast-growing Norway spruce (Picea abies) clones, Microbial Ecol., 56, 76-89, 2008.

Kubartová, A., Moukoumi, J., Béguiristain, T., Ranger, J., and Berthelin, J.: Microbial diversity during cellulose decomposition in different forest stands: I. Microbial communities and environmental conditions, Microbial Ecol., 54, 393-405, 2007.

Kurz-Besson, C., Coûteaux, M. M., Thiéry, J. M., Berg, B., and Remacle, J.: A comparison of litterbag and direct observation methods of Scots pine needle decomposition measurement, Soil Biol. Biochem., 37, 2315-2318, 2005.

Laiho, R., Vasander, H., Penttilä, T., and Laine, J.: Dynamics of plant-mediated organic matter and nutrient cycling following water-level drawdown in boreal peatlands, Global Biogeochem. Cy., 17, 1053, doi:10.1029/2002GB002015, 2003.

Laiho, R.: Decomposition in peatlands: Reconciling seemingly contrasting results on the impacts of lowered water levels, Soil Biol. Biochem., 38, 2011-2024, 2006.

Laine, J., Vasander, H., and Laiho, R.: Long-term effects of water level drawdown on the vegetation of drained pine mires in southern Finland, J. Appl. Ecol., 32, 785-802, 1995a.

Laine, J., Vasander, H., and Sallantaus, T.: Ecological effects of peatland drainage for forestry, Environ. Rev., 3, 286-303, $1995 \mathrm{~b}$.

Laine, J., Komulainen, V.-M., Laiho, R., Minkkinen, K., Rasinmäki, A., Sallantaus, T., Sarkkola, S., Silvan, N., Tolonen, K., Tuittila, E.-S., Vasander, H., and Päivänen, J.: Lakkasuo a guide to mire ecosystem, Department of Forest Ecology Publications, University of Helsinki, 31, 123 pp., 2004.

Limpens, J., Berendse, F., Blodau, C., Canadell, J. G., Freeman, C., Holden, J., Roulet, N., Rydin, H., and Schaepman-Strub, G.: Peatlands and the carbon cycle: from local processes to global implications - a synthesis, Biogeosciences, 5, 1475-1491, doi:10.5194/bg-5-1475-2008, 2008.

Lepš, J. and Šmilauer, P.: Multivariate analysis of ecological data using CANOCO, Cambridge University Press, Cambridge, 2003. 
Minkkinen, K., Byrne, K. A., and Trettin, C.: Climate impacts of peatland forestry, in: Peatlands and climate change, edited by: Strack, M., International Peat Society, Jyväskylä, 98-122, 2008.

Minkkinen, K., Laine, J., and Hökkä, H.: Tree stand development and carbon sequestration in drained peatland stands in Finland a simulation study, Silva Fenn, 35, 55-69, 2001.

Nannipieri, P., Kandeler, E., and Ruggiero, P.: Enzyme activities and microbiological and biochemical processes in soil, in: Enzymes in the Environment: Activity, Ecology and Applications, eduted by: Burns, R. G. and Dickand, R. P., Marcel Dekker, New York, 1-33, 2002.

Niemi, R. M. and Vepsäläinen, M.: Stability of the fluorogenic enzyme substrates and $\mathrm{pH}$ optima of enzyme activities in different Finnish soils, J. Microbiol. Meth., 60, 195-205, 2005.

Nübel, U., Engelen, B., Felske, A., Snaidr, J., Wieshuber, A., Amann, R. I., Ludwig, W., and Backhaus, H.: Sequence heterogeneities of genes encoding 16S rRNAs in Paenibacillus polymyxa detected by temperature gradient gel electrophoresis, J. Bacteriol., 178, 5636-5643, 1996.

Peltoniemi, K.: Aerobic carbon-cycle related microbial communities in boreal peatlands: responses to water-level drawdown. Dissertationes Forestales, 101, Finnish Society of Forest Science, Helsinki, 54 p., http://www.metla.fi/dissertationes/df101. htm, 2010.

Peltoniemi, K., Fritze, H., and Laiho, R.: Response of fungal and actinobacterial communities to water-level drawdown in boreal peatland sites, Soil Biol. Biochem., 41, 1902-1914, 2009.

Pennanen, T., Caul, S., Daniell, T. J., Griffiths, B. S., Ritz, K., and Wheatley, R. E.: Community-level responses of metabolicallyactive soil microorganisms to the quantity and quality of substrate inputs, Soil Biol. Biochem., 36, 841-848, 2004.

Rejmánková, E., and Sirová, D.: Wetland macrophyte decomposition under different nutrient conditions: relationships between decomposition rate, enzyme activities and microbial biomass, Soil Biol. Biochem., 39, 526-538, 2007.

Robroek, B. J. M., Limpens, J., Breeuwer, A., and Schouten, M. G. C.: Effects of water level and temperature on performance of four Sphagnum mosses, Plant Ecol., 190, 97-107, 2007.

Romaní, A. M., Fischer, H., Mille-Lindblom, C., and Tranvik, L. J.: Interactions of bacteria and fungi on decomposing litter: Differential extracellular enzyme activities, Ecology, 87, 2559-2569, 2006.

Roulet, N., Moore, T., Bubier, J., and Lafleur, P.: Northern fens: methane flux and climatic change, Tellus 44B, 100-105, 1992.

Sarkkola, S., Hökkä, H., Koivusalo, H., Nieminen, M., Ahti, E., Päivänen, J., and Laine, J.: Role of tree stand evapotranspiration in maintaining satisfactory drainage conditions in drained peatlands, Can. J. For. Res., 40, 1485-1496, 2010.

Schlotzhauer, S. M. and Price, J. S.: Soil water flow dynamics in a managed cutover peat field, Quebec: Field and laboratory investigations, Water Resour. Res,, 35, 3675-3683, 1999.

Schulze, E. D. and Freibauer, A.: Carbon unlocked from soils, Nature, 437, 205-206, 2005.

Sinsabaugh, R. L.: Enzymic analysis of microbial pattern and process, Biol. Fertil. Soils, 17, 69-74, 1994.

Sinsabaugh, R. L., Carreiro, M. M., and Repert, D. A.: Allocation of extracellular enzymatic activity in relation to litter composition, $\mathrm{N}$ deposition, and mass loss, Biogeochemistry, 60, 1-24, 2002.
Straková, P., Anttila, J., Spetz, P., Kitunen, V., Tapanila, T., and Laiho, R.: Litter quality and its response to water level drawdown in boreal peatlands at plant species and community level, Plant. Soil., 335, 501-520, doi:10.1007/s11104-010-044762010, 2010.

Strickland, M. S., Osburn, E., Lauber, C., Fierer, N., and Bradford, M. A.: Litter quality is in the eye of the beholder: initial decomposition rates as a function of inoculum characteristics, Funct. Ecol., 23, 627-636, 2009.

Suding, K. N., Lavorel, S., Chapin, F. S., Cornelissen, H., Diaz, S., Garnier, E., Goldberg, D., Hooper, D. U., Jackson, S. T., and Navas, M. L.: Scaling environmental change through the community-level: a trait-based response-and-effect framework for plants. Glob. Change Biol., 14, 1125-1140, 2008.

Tabatabai, M. A.: Soil enzymes, in: Methods of Soil Analyses: Part 2. Microbiological and Biochemical Properties, edited by: Weaver, R. W., Angle, J. S., and Bottomly, P. S., Soil Science Society of America, Madison, WI, USA, 775-833, 1994.

Taylor, B. R.: Air-drying depresses rates of leaf litter decomposition, Soil Biol. Biochem., 30, 403-412, 1998.

ter Braak, C. J. F. and Šmilauer, P.: CANOCO Reference Manual and CanoDraw for Windows User's guide: Software for Canonical Community Ordination (version 4.5). Microcomputer Power, Ithaca, USA, 2002.

Thormann, M. N.: Diversity and function of fungi in peatlands: A carbon cycling perspective, Can. J. Soil Sci., 86, 281-293, 2006.

Thormann, M. N., Bayley, S. E., and Currah, R. S.: Microcosm tests of the effects of temperature and microbial species number on the decomposition of Carex aquatilis and Sphagnum fuscum litter from southern boreal peatlands, Can. J. Microbiol., 50, 793-802, 2004.

Toberman, H., Laiho, R., Evans, C., Artz, R., Fenner, N., Straková, P., and Freeman, C.: Long-term drainage for forestry inhibits extracellular phenol oxidase activity in Finnish boreal mire peat, Eur. J. Soil Sci., 61, 950-957, 2010.

Vainio, E. J. and Hantula, J.: Direct analysis of wood-inhabiting fungi using denaturing gradient gel electrophoresis of amplified ribosomal DNA, Mycol. Res., 104, 927-936, 2000.

Vepsäläinen, M., Erkomaa, K., Kukkonen, S., Vestberg, M., Wallenius, K., and Niemi, R. M.: The impact of crop plant cultivation and peat amendment on soil microbial activity and structure, Plant. Soil., 264, 273-286, 2004.

Vepsäläinen, M., Kukkonen, S., Vestberg, M., Sirviö, H., and Niemi, R. M.: Application of soil enzyme activity test kit in a field experiment, Soil Biol. Biochem., 33, 1665-1672, 2001.

Weltzin, J. F., Bridgham, S. D., Pastor, J., Chen, J. Q., and Harth, C.: Potential effects of warming and drying on peatland plant community composition, Glob. Change Biol., 9, 141-151, 2003.

Weltzin, J. F., Pastor, J., Harth, C., Bridgham, S. D., Updegraff, K., and Chapin, C. T.: Response of bog and fen plant communities to warming and water-table manipulations, Ecology, 81, 3464$3478,2000$. 